\title{
The Wnt-dependent signaling pathways as target in oncology drug discovery
}

\author{
Nico Janssens ${ }^{1}$, Michel Janicot ${ }^{2}$ and Tim Perera ${ }^{2}$ \\ ${ }^{1}$ Department of Biochemistry, University of Antwerp, Wilrijk, Belgium; ${ }^{2}$ Johnson \& Johnson Pharmaceutical $R \&$ D, \\ Oncology Discovery Research \& Early Development, Beerse, Belgium
}

Published online: 28 January 2006

Keywords: Wnt, Fzd, signaling pathway, drug target, oncology, review, $\beta$-catenin, LRP5, sFRP1, cancer, NSAIDS, exisulind, retinoids, endostatin, curcumin, folic acid, HDAC inhibitors, GSK3, Gleevec.

\begin{abstract}
Abbreviations APC: adenomatous polyposis coli, $\beta$-TrCP: $\beta$-Transducin repeat Containing Protein, CBP: CREB binding protein, CK1: Casein Kinase 1, CREB: cAMP-response element binding protein, CtBP: $C$-terminal Binding Protein; DKK: Dickkopf, Dvl: Disheveled, EGFR: epidermal growth factor receptor, ERK: extracellular-regulated kinase, ES: endostatin, FAP: familial adenomatous polyposis, FEVR: familial exudative vitreoretinopathy, Fzd: Frizzled;, GPCR: G-protein coupled receptor, GSK3 $\beta$ : glycogen synthase kinase $3 \beta$, HAT: histone acetyltransferase, HDAC: histone deacetylase, HGF: hepatocyte growth factor, IGF: insulin-like growth factor, LDL: low-density lipoprotein, LRP: LDLreceptor-related protein, MMP: matrix metalloproteinase, NLK: Nemo-like kinase, NMR: nuclear magnetic resonance, NSAID: non-steroidal anti-inflammatory drugs, PCP: planar cell polarity, PDE: phosphodiesterase, PDGF: platelet derived growth factor, PKC: Protein kinase C, PKG: Protein kinase G, PPAR: peroxisome proliferator-activated receptor, RA: retinoic acid, RXR: retinoic X receptor, SAANDs: Selective Apoptotic Anti-Neoplastic Drugs, sFRP: secreted Frizzled related protein, SNP: single nucleotide polymorphism, TSA: Trichostatin A, VEGF: vascular endothelial growth factor, VPA: valproic acid; WIF, Wnt inhibitory factor
\end{abstract}

\section{Summary}

Our current understanding of the Wnt-dependent signaling pathways is mainly based on studies performed in a number of model organisms including, Xenopus, Drosophila melanogaster, Caenorhabditis elegans and mammals. These studies clearly indicate that the Wnt-dependent signaling pathways are conserved through evolution and control many events during embryonic development. Wnt pathways have been shown to regulate cell proliferation, morphology, motility as well as cell fate. The increasing interest of the scientific community, over the last decade, in the Wnt-dependent signaling pathways is supported by the documented importance of these pathways in a broad range of physiological conditions and disease states. For instance, it has been shown that inappropriate regulation and activation of these pathways is associated with several pathological disorders including cancer, retinopathy, tetra-amelia and bone and cartilage disease such as arthritis. In addition, several components of the Wnt-dependent signaling pathways appear to play important roles in diseases such as Alzheimer's disease, schizophrenia, bipolar disorder and in the emerging field of stem cell research. In this review, we wish to present a focused overview of the function of the Wnt-dependent signaling pathways and their role in oncogenesis and cancer development. We also want to provide information on a selection of potential drug targets within these pathways for oncology drug discovery, and summarize current data on approaches, including the development of small-molecule inhibitors, that have shown relevant effects on the Wnt-dependent signaling pathways.

\section{Introduction}

The Wnt-dependent signaling pathways comprise several branches whose differential activation depends on the specificity of the Wnt ligands and Frizzled (Fzd) isoforms involved, as well as the cellular context. These pathways and their implication in several disease states have attracted a lot of interest, both from academia and the pharmaceutical industry, due mainly to the fact that components of these pathways may act as 
good targets for drug discovery. In this review, we will discuss the recent progress in understanding the regulation of the Wnt-dependent signaling pathways and their physiological role in human cancer, as well as present some perspectives on the therapeutic potential provided by targeted intervention of the Wnt pathways, including the development of small molecule inhibitors of the Wnt pathways in oncology drug discovery research.

\section{Overview of the Wnt-dependent signaling pathways}

The Wnt-dependent signaling pathways encompass three different molecular pathways downstream of Wnt/Fzd interaction. The majority of published research on Wnt signaling has been focused on the $\mathrm{Wnt} / \beta$-catenin pathway, which regulates cell fate determination by regulating gene expression. The $\mathrm{Wnt} / \beta$-catenin pathway is also referred to as the "canonical" Wnt pathway. The Wnt/Ca ${ }^{2+}$ and Wnt/polarity (also known as Planar Cell Polarity, PCP) pathways are known as the "non-canonical pathways", and the identity of the components of both these pathways has been unclear until recently. The intracellular signal transduction cascades that have been identified in each of these pathways are very different from each other, but the common initial step is the binding of a Wnt ligand to the cognate Fzd receptor. Depending on the pathway which is activated, the initiation signal will be transduced differently. This decision most likely depends on which Wnt ligand and FZD receptor are present, as well as the cellular context. Nineteen Wnt ligands and 10 different members of the Fzd seven-transmembrane receptor family have been described in the human genome (http://www.stanford.edu/ rnusse/wntwindow.html).

Consequently, a large variety of responses could be initiated from Wnt/Fzd interactions.

The different Wnt ligands have been classified into two functional groups. The first group, referred to as the protooncogenic or transforming group (e.g., Wnt1, $-3 \mathrm{~A},-8$ and $-8 \mathrm{~B})$, induce a secondary axis in early Xenopus embryos [1] and transform C57MG mammary epithelial cells [2, $3]$ when ectopically expressed. In general, this group can activate the $\beta$-catenin pathway. The second group (e.g., Wnt4, -5A and -11) do not elicit axis duplication in Xenopus embryos [1] and cannot transform C57MG cells [3]. However, these Wnts alter cell movements and reduce cell adhesion when over-expressed in Xenopus embryos $[1,4]$. These Wnts can activate the non-canonical Wnt pathways, as well as antagonize the activity of the transforming Wnts [5]. This classification is not exclusive, for instance, Wnt5a has been shown to activate non-canonical pathways, but when co-expressed with Fzd5, it can induce axis duplication (canonical pathway) [6].
Fzd receptors can be classified into several groups based on their basal signaling activity when ectopically expressed in Xenopus. In this context, in the absence of ectopic ligand, members of the Fzd family preferentially activate either the $\beta$-catenin or the $\mathrm{Ca}^{2+}$ pathway [7]. As shown in Figure 1, there are 4 families of Wnt antagonists that can be divided into two sub-groups according to their mode of action. The first group includes the secretedFrizzled related protein (sFRP) family, Wnt-inhibitory factor-1 (WIF-1), and Cerberus. They inhibit Wnt signaling by direct binding to Wnt molecules. The second group, consisting of the Dickkopf (DKK) family, inhibits Wnt signaling by binding to the LRP5/LRP6 component of the Wnt receptor complex [8].

The Wnt/ $\beta$-catenin pathway has been extensively studied in different vertebrate and invertebrate model systems and it was shown that $\beta$-catenin is the central molecule. The pathway requires an additional single-pass transmembrane protein, known as LRP5 or LRP6 from the low-density-lipoprotein (LDL) receptor family, to function as an obligate co-receptor of the seventransmembrane Fzd receptors for transducing the Wnt signal [9-11]. The amino-termini of LRP and FZD were reported to associate only in the presence of Wnt [12], implying that Wnt ligands form a trimeric complex with an LRP and FZD receptor. However, it was recently reported that LRPs activate the Wnt $/ \beta$-catenin pathway by binding to Axin in a disheveled (Dvl) independent manner, while Fzd receptors transduce Wnt signals through Dvl to stabilize $\beta$-catenin [13]. It is thus possible that Wnt proteins form separate complexes with Fzd receptors and LRPs, transducing the signals separately, but converging downstream in the $\mathrm{Wnt} / \beta$-catenin pathway. The current model of $\mathrm{Wnt} / \beta$-catenin activation starts with the binding of Wnt to a receptor complex encompassing a Fzd receptor and LRP co-receptor. The biochemical mechanisms by which the binding of the Wnt ligand to its cognate Fzd receptor elicits signal transduction within the cell are poorly characterized. After Wnt binding, Dvl is phosphorylated and through its association with Axin, prevents glycogen synthase kinase $3 \beta$ (GSK3 $\beta$ ) and casein kinase $1 \alpha(\mathrm{CK} 1 \alpha)$ from phosphorylating critical substrates, including $\beta$-catenin. Phosphorylation of $\beta$-catenin at the $N$-terminus by CK $1 \alpha$ and GSK3 $\beta$ is essential for its targeted degradation [14]. Non-phosphorylated $\beta$-catenin escapes recognition by $\beta$-Transducin repeat Containing Protein $(\beta$-TrCP), a component of an E3 ubiquitin ligase complex, thereby avoiding degradation. This non-phosphorylated form of $\beta$-catenin is then able to localize to the nucleus [15], form a complex with Tcf/Lef transcription factors and co-activators such as (CREB Binding Protein, CBP) [16, 17] and induce the expression of downstream target genes (see http://www.stanford.edu/ rnusse/wntwindow.html). Al- 


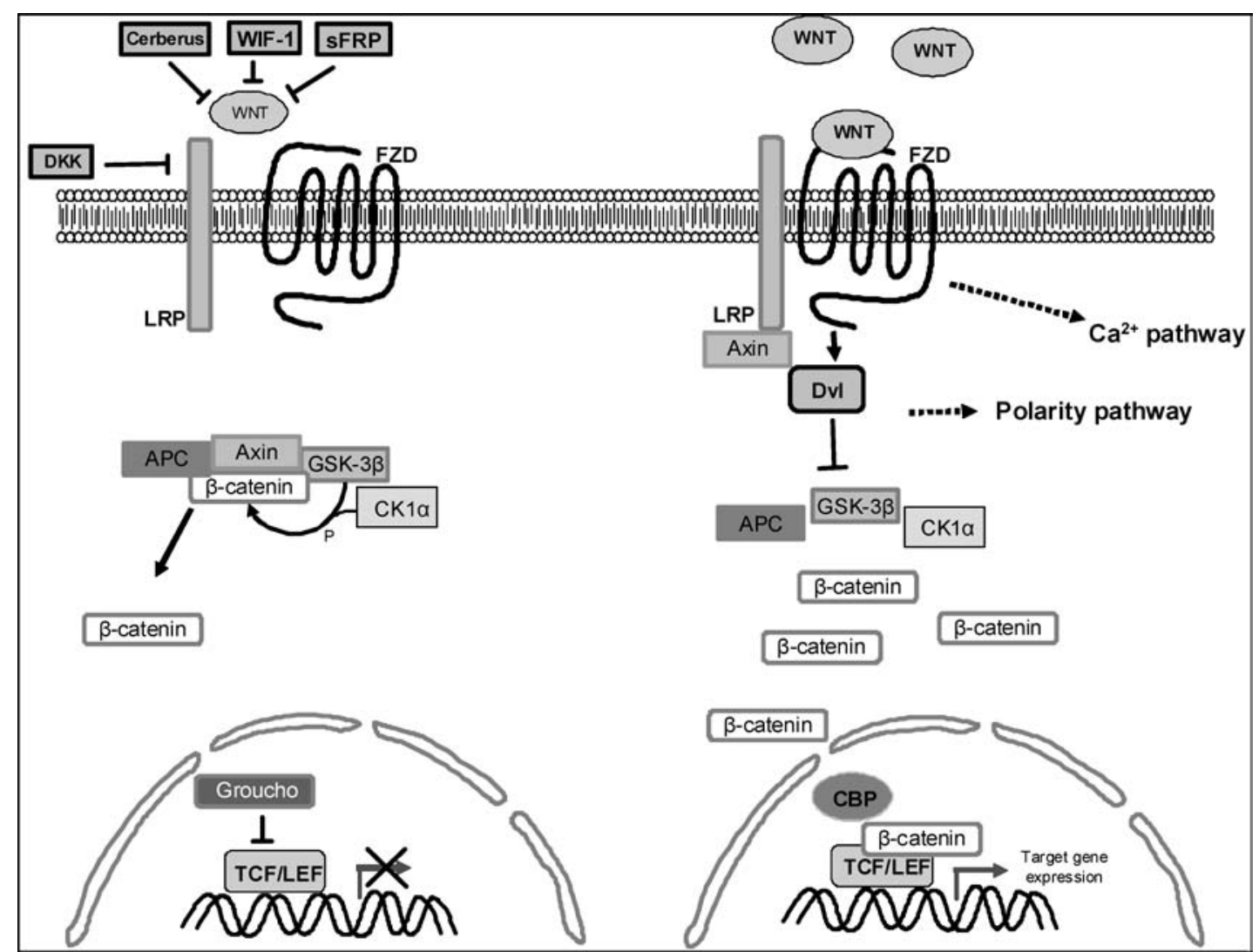

Figure 1. Schematic overview of the Wnt signaling pathways. In the absence of active Wnt (left) $\beta$-catenin is degraded and Tcf/Lef transcription factors act as repressor. When a Wnt signal is present (right) $\beta$-catenin accumulates in the cytoplasm, localizes then to the nucleus, and activates transcription together with Tcf/Lef transcription factors.

though Tcf/Lef directly bind to DNA through their HMG domains, they are incapable of independently activating gene transcription [18]. $\beta$-catenin is the additional co-activator required for transcriptional activation [19] together with other co-activators such as CBP [20]. In the absence of a Wnt/Fzd signal, $\beta$-catenin is phosphorylated by GSK $3 \beta$ and $\operatorname{CK} 1 \alpha$, subsequently ubiquinated and rapidly degraded by the proteasome. $\beta$-catenin levels will not be able to accumulate in the nucleus, and $\mathrm{Tcf} /$ Lef proteins will act as transcriptional repressor, mediated through the interaction of Tcf/Lef with at least two different gene products, Groucho and $C$-terminal Binding Protein (CtBP) [17, 21-23].

Signaling through the $\mathrm{Wnt} / \mathrm{Ca}^{2+}$ pathway is independent of $\beta$-catenin. The $\mathrm{Wnt} / \mathrm{Ca}^{2+}$ pathway regulates cell adhesion and motility [24], and is mediated through release of intracellular $\mathrm{Ca}^{2+}$ upon Wnt stimulation, and involves activation of protein kinase $\mathrm{C}$ (PKC) and calcium/calmodulin-dependent kinase II (CamKII) [25-27], leading to the regulation of the $\mathrm{Ca}^{2+}$-responsive transcription factor NF-AT [28, 29]. Wnt-5a was the first Wnt ligand identified to signal down this pathway and was shown to require coupling to $G$-proteins $[26,30]$. Inter- estingly, the $\mathrm{Wnt} / \mathrm{Ca}^{2+}$ pathway activated by Wnt-5a, antagonizes the $\mathrm{Wnt} / \beta$-catenin pathway $[1,5,29,31]$. One mechanism of inhibition is via CamKII. CamKII will activate the MAP kinase-related Nemo-like kinase (NLK), which will phosphorylate Tcf transcription factors, which will prevent $\beta$-catenin/Tcf-mediated transcription [31, 32]. In addition, $\mathrm{PKC}$, activated by the $\mathrm{Wnt} / \mathrm{Ca}^{2+}$ pathway, has been shown to block the Wnt $/ \beta$-catenin pathway by phosphorylating Dvl [33].

In the Wnt/polarity pathway, referred to as the Planar Cell Polarity (PCP) pathway in Drosophila, Fzd functions to establish asymmetric cell polarities and coordinate cell shape changes and cellular movement. Much of the current understanding of the molecules governing this pathway has come from studies in Drosophila as several clear effects of the PCP pathway, such as hair follicle and bristle orientation, can be readily assessed in this organism. In addition, the existence of mutant genes that affect planar polarized structures in Drosophila have been exploited to study the processes governing PCP. In this pathway, Fzd regulates the activity of the small GTPases Rho and Rac through different domains of Dvl. Rho and Rac, in turn, regulate the activity of Rock and Jun N-terminal Kinase 
(JNK) respectively [34-36]. PCP was recently demonstrated in a mammalian system - mammalian cochleain which the PCP pathway initiated by Wnt7a governs the unidirectional orientation of sensory hair cells necessary for unimpaired hearing [37]. The PCP pathway is also involved in regulating cell polarization during vertebrate gastrulation movements $[5,36,38,39]$ in which activation of both Rho and Rac are required for convergent extension [36]. Thus, although differences exist between vertebrate and invertebrate pathways, the core components of the pathway are conserved through evolution.

\section{Implication of Wnt-dependent signaling pathways in Oncology}

The first Wnt (at that time still known as int1) was discovered more than 20 years ago [40], as a proto-oncogene in mammary tumors activated by integration of the mouse mammary tumor virus. Since then, more studies have linked the Wnt-dependent signaling pathways to oncogenesis and cancer development. While the Wnt pathways have been the focus of a great deal of experimentation with increasing number of reports and publications every year, a number of questions still remain to be answered. As the downstream components were identified, more studies have found evidence linking the different components of these pathways to cancer [41-44] as well as other indications (Table 1).

Definitive proof of the involvement of Wnts in human cancer has been lacking for years. There have been numerous reports describing either over-expression or, sometimes, under-expression of Wnt genes in human cancers, but mRNA expression levels can at best be correlative. A transgenic mouse model has recently shown that tumor growth is dependent on Wnt-1 expression [45]. Studies of Wnt expression in human breast tumors have tended to support a role for Wnt signaling in the development of breast cancer [46-50]. Wnt5a signaling has also been shown to directly affect cell motility and invasion of metastatic melanoma. Blocking this pathway using antibodies to Fzd5, a receptor for Wnt5a, was shown to inhibit PKC activity and cellular invasion. Furthermore, Wnt5a expression in human melanoma biopsies directly correlated with increasing tumor grade [51]. More compelling evidence, such as amplification, rearrangements, or mutation of genes encoding Wnt ligands or receptors has thus far not been identified. Chen and colleagues showed that cells expressing Wnt 1 were resistant to cancer therapy mediated apoptosis. Wnt1 signaling inhibited cytochrome $\mathrm{c}$ release and the subsequent caspase-9 activation that was induced by chemotherapeutic drugs, including both vincristine and vinblastine. Further research showed that Wnt 1 signaling inhibited apoptosis by activating $\beta$-catenin/Tcf mediated transcription [52]. It was
Table 1. Wnt-dependent signaling pathway components involved in diseases and syndromes (adapted from [185])

\begin{tabular}{|c|c|c|c|}
\hline Gene & Disease & $\begin{array}{l}\text { Mutation or ac- } \\
\text { tivity/expression } \\
\text { change }\end{array}$ & Reference \\
\hline Wnt(s) & Cancer & Elevated & {$[47,186]$} \\
\hline Wnt5a & Cancer/metastasis & Elevated & {$[51]$} \\
\hline $\mathrm{sFRP}(\mathrm{s})$ & Cancer & Variable & {$[55,56,59]$} \\
\hline WIF-1 & Cancer & Reduced & {$[63]$} \\
\hline LRP5 & Osteosarcoma & Elevated & {$[68]$} \\
\hline $\operatorname{Fzd}(\mathrm{s})$ & Cancer & Elevated & [187] \\
\hline$\beta$-catenin & Cancer & Gain of function & [41] \\
\hline APC & Cancer & $\begin{array}{l}\text { Loss of function/ } \\
\text { reduced }\end{array}$ & {$[78,79]$} \\
\hline Axin & Cancer & Loss of function & {$[83]$} \\
\hline GSK $3 \beta$ & Cancer & Deregulated & {$[188,189]$} \\
\hline Wnt1 & Schizophrenia & Elevated & {$[190]$} \\
\hline GSK3 $\beta$ & Schizophrenia & Variable & [191] \\
\hline Fzd3 & Schizophrenia & SNP & [192] \\
\hline Wnt1 & $\begin{array}{c}\text { Rheumatoid } \\
\text { arthritis }\end{array}$ & Elevated & [193] \\
\hline Wnt5a & $\begin{array}{l}\text { Rheumatoid } \\
\text { arthritis }\end{array}$ & Elevated & {$[193,194]$} \\
\hline Fzd5 & $\begin{array}{c}\text { Rheumatoid } \\
\text { arthritis }\end{array}$ & Elevated & {$[193,194]$} \\
\hline sFRP3 & Osteoarthritis & $\mathrm{SNP} /$ reduced & [195] \\
\hline LRP5 & Low bone mass & Loss of function & [69] \\
\hline LRP5 & High bone mass & Gain of function & {$[70,196]$} \\
\hline Wnt3 & Tetra-amelia & Loss of function & [197] \\
\hline Fzd4 & FEVR & Loss of function & [198] \\
\hline LRP5 & FEVR & Loss of function & [199] \\
\hline Wnt4 & Intersex & Variable & {$[200,201]$} \\
\hline
\end{tabular}

APC: adenomatous polyposis coli; FEVR: familial exudative vitreoretinopathy; Fzd: Frizzled; GSK3 $\beta$ : glycogen synthase kinase $3 \beta$; LRP: LDL-receptor-related protein; sFRP: secreted Frizzled related protein; SNP: single nucleotide polymorphism; WIF: Wnt inhibitory factor.

recently demonstrated that inhibition of Wnt 2 mediated signaling induced apoptosis in both malignant melanoma cells and non-small-cell lung cancer cells $[53,54]$. These studies show that activation of the $\beta$-catenin/Tcf signaling pathway by Wnt ligands not only provides a growth advantage to cancer cells, but also significantly affects the clinical outcome by inhibiting chemotherapy-induced apoptosis. Blocking Wnt signaling, for instance with a monoclonal antibody or development of small molecules can be useful to inhibit the $\mathrm{Wnt} / \beta$-catenin signaling pathway for treatment of cancer patients and may improve the efficacy of chemotherapy by enhancing apoptosis in cancer cells. 
The Wnt signaling pathway antagonists have also been studied extensively in developmental studies and their involvement in oncogenesis was recently demonstrated. Loss of expression of sFRP1 was reported in bladder cancer [55], and down-regulation of family members has been reported in cervical carcinomas [56], breast cancers [57], and gastric cancers [58], whilst the promoters of several sFRP family members have been shown to be hypermethylated in colorectal tumors [59-61]. WIF-1 downregulation was recently reported by Wissman and colleagues in several cancer types including lung cancer [62] and it was shown that WIF-1 was frequently silenced by hypermethylation of its promoter in lung cancer cell lines as well as in fresh lung cancer tissues [63].

Both Fzd and its co-receptor LRP have also been implicated in carcinogenesis although clear proof is lacking. Expression studies for the Fzd genes have indicated that aberrant expression of these genes is involved in human cancer [7, 46, 49, 58, 64-67], and LRP5 was identified as a possible marker for disease progression in high-grade osteosarcoma [68]. The presence of LRP5 correlated significantly with tumor metastasis and the chondroblastic subtype of osteosarcoma. Patients with LRP5 expression in the tumor showed decreased event free survival. In addition, mutations in LRP5 have been linked to diseases with significant skeletal abnormalities [69, 70].

The most compelling evidence implicating the Wnt signaling pathway in carcinogenesis is the observation that $\beta$-catenin functions as an oncogene in different cancers, while APC and Axin act as tumor suppressor genes. Mutations in the $\beta$-catenin gene, affecting the aminoterminal region of the protein, increase the stability of the $\beta$-catenin gene. These mutations affect specific serine and threonine residues, which are sites for priming by CK1 (Ser 45) and further phosphorylation by GSK3 $\beta$ (Ser 33, 37 and Thr 41) and are essential for the recognition by $\beta$-TrCP, marking $\beta$-catenin for degradation [71]. Somatic mutations in the amino-terminal region of the $\beta$-catenin gene have been described in a wide variety of human cancers, including colorectal, endometrial, ovarian, pancreatic, hepatocellular, prostate, gastric and thyroid carcinoma, desmoid tumor, hepatoblastoma, medulloblastoma, melanoma, pilomatricoma, squamous cell carcinoma of the head and neck, and Wilms' tumor [41].

Both APC and Axin have a regulatory function in the Wnt signaling pathway, and both have been shown to be critical for the down-regulation of $\beta$-catenin [72-74]. It has been proposed that Axin and APC facilitate the phosphorylation of $\beta$-catenin by GSK3 $\beta$ [75-76]. About $80 \%$ of sporadic colorectal carcinomas and cell lines derived from these tumors harbor mutations in the APC gene $[77,78]$, Most of them are nonsense or frame shift mutations leading to a truncated APC protein. About $60 \%$ of these mutations are clustered in a 700 bp "mutation clus- ter region" corresponding to the $\beta$-catenin/Axin-binding domain. Apart from APC mutations, hypermethylation of the APC promoter at $\mathrm{CpG}$ sites was also detected in colorectal cancer [79], which may thus constitute an alternative mechanism for APC gene inactivation. Beside the important role of APC in regulating $\beta$-catenin levels, it has additional functions through its binding and stabilization of microtubules [80], and truncation of the APC gene could lead to chromosomal instability, which is a hallmark of colorectal cancer [81, 82]. The high prevalence of APC mutations in colorectal cancers makes identification of these mutations a worthwhile strategy for diagnosis and early detection of colorectal carcinomas. Axin has also been shown to be mutated in hepatocellular cancer and the derivative cell lines [83]. All of the mutations were predicted to truncate the Axin protein in a manner that eliminated the $\beta$-catenin binding sites, and thus preventing Axin from facilitating $\beta$-catenin phosphorylation and degradation.

Finally, all previously discussed aberrations and mutations in components of the Wnt-dependent signaling pathways lead to activation of Tcf/Lef target genes by $\beta$-catenin. A considerable number of target genes have been identified (see Wnt homepage for a complete list) and play a role in development and tumorigenesis. Several of the target genes have functions in cell cycle, apoptosis, proliferation, transcription and are involved in tumor progression. The first identified target genes were c-Myc and cyclin D1 $[84,85]$ through which Wnt signaling may stimulate progression through the cell cycle. Other target genes that have been identified include, for instance, vascular endothelial growth factor (VEGF), Wnt-1 induced secreted protein 1 (WISP-1), Bone morphogenetic protein-4 (BMP-4), matrix metalloproteinase (MMP) 7 and 26. The list of downstream target genes will undoubtedly be extended and it will be interesting to elucidate the relevance of these genes for human cancers.

As discussed, many genes in this pathway have been implicated in neoplasia through mutations (APC, Axin, $\beta$-catenin), and several other components through upor downregulated expression. However, variations in expression levels (up- and downregulation) are also found in normal cells at different stages of development. Since the Wnt signaling pathway is crucial for normal development, the expression level of the different genes in adult tissues can be considered as relevant for cancer research. With the advent of high-throughput methods that evaluate gene-expression in tumors [86-88], the discovery of genes that are differentially expressed has been increasing exponentially. The information gained from these studies has proven promising for the development of diagnostic assays, particularly for prognosis, but the utility of a gene as a cancer diagnostic does not necessarily reflect a causative role in the process [89]. In the absence of muta- 
tional evidence, functional evidence obtained from studies in vitro or in non-human species in vivo must be used. Levels of gene expression are thus unreliable indicators of causation because disturbance of any network invariably leads to a multitude of such changes only peripherally related to the phenotype [90]. Taken together, it is apparent that aberrant Wnt signaling can cause cancer and that tumor promotion by this pathway can proceed through different genetic defects that occur at several stages of this pathway. Many different types of cancer, in different tissues, have been linked to alterations in the Wnt signaling pathway and it is thus not surprising that oncology is the main disease area where antagonists of this pathway could be of use.

\section{Existing therapies with non-specific effects on Wnt-dependent signaling pathways}

As a result of all the evidence implicating Wnt signaling in the pathophysiology of many human diseases, including cancer, interest in the development of Wnt signaling inhibitors has increased substantially. Different components of these signaling pathways can be regarded as useful targets in preventing and treating cancer, and several therapeutic approaches currently being exploited may already be linked to Wnt pathways, although their actual mechanism of action remain unclear. The development of new targeted anticancer agents is based on the premise that the drug modulates a specific molecular target. These targets may be critical to cancer cell survival or may be a regulatory pathway not used in normal cells. In the next sections, we will discuss a number of therapies that have a non-specific effect on the Wnt signaling pathways.

Non-Steroidal Anti-Inflammatory Drugs (NSAIDs) such as aspirin, indomethacin and sulindac - have been demonstrated to act as anti-tumor agents [91, 92]. Regular use of NSAIDs is shown to be associated with a reduced incidence of some cancers including breast and colorectal carcinomas. Epidemiological studies have documented a decreased risk of colorectal cancer deaths associated with use of aspirin. Combined case-control data, including over 30,000 colorectal cancer cases, indicated a $45 \%$ reduction in the risk of developing colorectal cancer in subjects taking NSAIDs [93]. In individuals with familial adenomatous polyposis (FAP), an inherited predisposition to multiple colorectal polyps (due to a mutation in APC), sulindac was shown to reduce both size and number of colorectal polyps [94]. Likewise, other NSAIDs have proven to be effective in the prevention of intestinal tumorigenesis in mouse models of FAP [95]. Studies from hereditary and sporadic colorectal cancer patients suggest that NSAIDs may interfere with the initiating steps of carcinogenesis; i.e., disturbance within the canonical Wnt signaling pathway. It was shown that both aspirin and indomethacin attenuated the transcription of $\beta$-catenin/Tcf-responsive genes by modulating Tcf activity without disrupting $\beta$-catenin/Tcf complex formation [96]. After further exploration of this mechanism, it was found that the reduced signaling activity of $\beta$-catenin in response to NSAIDs was a result of its enhanced phosphorylation [97]. Phosphorylation of amino-terminal Ser/Thr residues of $\beta$-catenin increased in response to aspirin and indomethacin in a time-dependent manner [97]. Another mechanism was shown by Nath $e t$ al. who demonstrated that aspirin inhibited $\beta$-catenin/Tcf signaling in colon cancer cells by disrupting nuclear $\beta$-catenin/Tcf [98]. This effect occurred far below the aspirin concentrations required to inhibit cell growth, and may be a critical early event in the chemopreventive activity of aspirin against colon cancer. These results have been confirmed by Boon et al. who provided in vitro and in vivo evidence that nuclear $\beta$-catenin localization and $\beta$-catenin/Tcf regulated transcription of target genes can be inhibited by sulindac [99]. In different experimental setups in vitro, sulindac also suppressed the formation of foci [100]. A recent study has shed more light on the effects of NSAIDs on $\beta$ catenin protein levels and $\beta$-catenin-related transcription in human colorectal cancer cells. Gardner et al. studied a panel of NSAIDs (indomethacin, diclofenac, sulindac sulphide and sulphone, rofecoxib) on SW480 human colorectal cancer cells. [101] All NSAIDs, except rofecoxib, were shown to decrease nuclear $\beta$-catenin content and cyclin D1 protein levels together with their anti-proliferative acitivity. [101] Many of the therapeutic effects of NSAIDs are attributed to inhibition of prostaglandin synthesis by inactivation of cyclooxygenase 1 and 2 (COX-1 and 2) $[96,102]$. The above mentioned studies demonstrate that COX-independent effects might be related to inhibition of Wnt signaling, since there is a clear link between the effects of NSAIDs as chemopreventive agents and $\beta$-catenin/Tcf activity [96]. New selective inhibitors of COX-2 (celecoxib and rofecoxib) are currently licensed for use in the treatment of arthritis and more recently in the chemoprevention of FAP [103]. Cardiovascular safety doubts recently put this class of compounds in the spotlight, and even led to the withdrawal of rofecoxib $\left(\right.$ Vioxx $\left.{ }^{\circledR}\right)$.

Exisulind (Aptosyn ${ }^{T M}$ ) is the lead compound of a new category of targeted anticancer agents-Selective Apoptotic Anti-Neoplastic Drugs (SAANDs) — and is an oxidative metabolite of the NSAID sulindac. Since exisulind lacks the cyclooxygenase inhibitory activity characteristic of NSAIDs, it is not an NSAID. Exisulind and analogs are inhibitors of cyclic GMP phosphodiesterases (PDE) and have been shown to increase kinase activity and induce the expression of protein kinase G (PKG). The antineoplastic effect of Exisulind appears to be the result of 
PKG activation which leads to multiple downstream effects culminating in apoptosis [104]. Activated PKG has been shown to phosphorylate $\beta$-catenin at its $C$-terminal domain, and to cause proteasome-dependent degradation of $\beta$-catenin, independent of APC and GSK $3 \beta$. As mentioned before, two pools of $\beta$-catenin exist, one associated with $E$-cadherin at the cell membrane, and a soluble one in the cytoplasm [105]. In the absence of Wnt, levels of $\beta$-catenin in the cytoplasmic pool are low due to targeted degradation of $\beta$-catenin. It has been however shown that $\beta$-catenin from the 2 pools can be exchanged, and that this exchange is strongly affected in cells that contain mutations in APC [106]. In cells with intact Wnt signaling, exisulind did not affect $\beta$-catenin levels [107]. Since most $\beta$-catenin is then found in bound form (to $E$-cadherin), phosphorylation by PKG may be prevented. In cell lines expressing APC or $\beta$-catenin mutations, in which $\beta$ catenin cannot be phosphorylated (N-terminal), exisulind was shown to induce cell death. Exisulind and analogs provide a potentially superior approach to circumvent the molecular defects of the Wnt signaling pathway and to treat cancers with such defects. Preclinical data evaluating SAANDs in combination with various chemotherapy drugs indicated additive or synergistic antineoplastic effects. In clinical studies, exisulind prevented colorectal polyp formation in patients with FAP over a 24 month period [104]. Although exisulind has highly promising features, it did not meet its end point in a Phase III clinical trial for chemoprevention in FAP and has not been approved by the FDA. However, it proved highly effective for polyp treatment with statistical significance in both an FAP crossover study and a large sporadic polyp trial [107].

Vitamin A derivatives (retinoids) are potent regulators of cell proliferation and differentiation. Retinoids have been shown to inhibit the function of the oncogenic AP-1 and $\beta$-catenin/Tcf pathways as well as stabilize components of the adherens junctions [108, 109]. Xiao et al. showed that retinoid $\mathrm{X}$ receptor (RXR) agonists induced degradation of $\beta$-catenin and $\mathrm{RXR} \alpha$ and repressed $\beta$ catenin-mediated transcription [110]. In in vivo experiments, it was shown that $\beta$-catenin interacted with $\operatorname{RXR} \alpha$ in the absence of ligand, and that RXR agonists enhanced the interaction, suggesting that RXR interacts with $\beta$-catenin in a retinoid-dependent manner, and thereby reducing $\beta$-catenin/Tcf regulated transcription. Since a chemopreventive activity by retinoic acid (RA) has been demonstrated in rat colon, Mollersen et al. studied dietary supplementation with all-trans RA in Min/+ mice [111]. In these Min/+ mice, which harbour a germline mutation in the tumor suppressor gene APC, they surprisingly showed that dietary RA significantly stimulated both the formation and growth of small intestinal tumors. Although contradictory, these results suggest a potential role for retinoids in the regulation of $\beta$-catenin turnover and related biological events. Both RA and vitamin D have been shown to have growth-inhibitory effects on colonic epithelial cells. For these reasons, both compounds have been suggested as potential candidates for chemoprevention of colorectal cancer. In the case of RA, its receptor is thought to compete with $\beta$-catenin for a common binding site on Tcf4. Vitamin D has been shown in breast carcinoma cells to increase cadherin expression, thereby decreasing cytosolic $\beta$-catenin and down-regulating $\beta$ catenin signaling by a second route [112].

Endostatin (ES) is a fragment of collagen XVIII that possesses anti-angiogenic activity. There is growing evidence that anti-angiogenic drugs, like ES, will improve future therapies of diseases like cancer, rheumatoid arthritis and ocular neovascularization.

In a recent paper, ES was described as a potential inhibitor of Wnt signaling [113]. To gain insight into ESmediated signaling, they studied the effects of ES RNA on Xenopus embryogenesis and observed developmental abnormalities consistent with impaired Wnt signaling. ES RNA blocked the axis duplication normally induced by $\beta$-catenin, partially suppressed Wnt-dependent transcription, and stimulated degradation of both wild-type and stabilized (degradation resistant through $\mathrm{N}$-terminal mutations) forms of $\beta$-catenin. They found that ES used a pathway independent of the Siah1 protein in targeting $\beta$-catenin for proteasome-mediated degradation. These data were replicated in endothelial cells and also in human DLD-1 colon carcinoma cells that contain a mutated APC gene [113]. Though high levels of ES were used in both Xenopus and endothelial cell studies and the effects on $\beta$-catenin signaling were modest, these data argue that at pharmacological concentrations ES may impinge on Wnt signaling and promote $\beta$-catenin degradation.

Curcumin (diferuloylmethane) is a natural plant product, and has been shown to exhibit chemopreventive activity [114]. Since current cancer treatments such as radioand chemotherapy are associated with severe side-effects and offer no firm expectation of a cure, there is a constant need for the investigation of other potentially useful options to prevent cancer. One of the most widely investigated approaches in cancer chemoprevention uses natural agents to reverse or inhibit the malignant transformation of cancer cells and to prevent invasion and metastasis. It was previously shown that Curcumin impairs both Wnt signaling and cell-cell adhesion pathways, resulting in $\mathrm{G}(2) / \mathrm{M}$ phase arrest and apoptosis although the exact mechanism remained unknown [115]. A more recent study showed that the reduced $\beta$-catenin/Tcf transcriptional activity was due to decreased nuclear $\beta$-catenin and Tcf4 [116]. Further studies are undoubtedly necessary to elucidate the mechanism(s) involved. Because Curcumin has been shown to intervene in several pathways with a high-level of safety and no toxicity, it has been proposed 
to be a wide-spectrum chemopreventive agent for cancer [117-119].

Folic acid may have a chemopreventive role in colon carcinogenesis, although the mechanism(s) of action is poorly understood. It has been shown that folic acid inhibited cell proliferation and EGF-receptor (EGFR) activation in colon cancer cells [120,121]. This effect was associated with a concomitant reduction in nuclear translocation of $\beta$-catenin [120]. Since the possible role of folic acid as an inhibitor of Wnt signaling has only recently been proposed more research would be necessary to understand the mechanism.

HDAC inhibitors The recruitment of histone acetyltransferases (HATs) and histone deacetylases (HDACs) is considered to be a key element in the dynamic regulation of many genes regulating cell proliferation and differentiation during normal development and carcinogenesis [122]. HDACs are usually subunits of multiprotein complexes and HDAC inhibitors are considered as very promising drug candidates for the treatment of leukemia, and various other forms of cancer [123-125]. In theory, inhibitors of HDAC may enable the re-expression of repressed regulatory genes in cancer cells and reverse the malignant phenotype. In the absence of the Wnt signal, nuclear Tcf acts as a repressor of Wnt target genes [126] by forming a complex with Groucho [21]. The repressive effect of Groucho has been shown to be mediated by interactions with HDACs [127]. $\beta$-catenin can convert Tcf into a transcriptional activator of the same genes that are repressed by Tcf alone (reviewed in [128]). It has been shown that sodium butyrate and Trichostatin A (TSA), inducers of $\mathrm{G}_{0}-\mathrm{G}_{1}$ cell cycle arrest and apoptosis in the SW620 colonic carcinoma cell line, up-regulate Tcf activity. Sodium butyrate and TSA are inhibitors of HDAC activity independent of their effects on $\beta$-catenin/Tcf signaling, and by altering chromatin structure they may render loci accessible to Tcf or other transcription factors [129]. This is in agreement with data shown by Ohira et al who have shown induction of the Wnt signaling pathway target gene, E-cadherin, by HDAC inhibition with TSA or GSK3 $\beta$ inhibition with $\mathrm{LiCl}$ and an additive or synergistic effect on E-cadherin expression with both inhibitors [130]. These studies suggest that HDACs help to repress the Tcf activity. HDAC inhibitors such as butyrate and TSA, block this repression resulting in a reduction of the threshold necessary to activate Tcf transcription. Tight regulation of transcription imposed by HDACs and HATs appears to be crucial for normal activity. When this regulation is lost through HDAC inhibitors, treated cells will go into cell cycle arrest and apoptosis. In Drosophila, Tcf has been shown to interact with CBP (CREB binding protein, histone acetylase), thereby repressing gene transcription when Wnt signaling is inactive [131]. In mammalian cells, CBP/P300 can also act as a co-activator of $\beta$-catenin/Tcf [20]. This might also turn out to be one of the mechanisms by which HDAC inhibitors function. Through inhibiting HDAC, CBP/P300 will no longer be able to function as a co-activator, and possibly even repress the $\beta$-catenin/Tcf signal. A recent study by Zhu et al. showed that loss of the APC tumor suppressor induced HDAC2 expression in solid tumors [125]. This upregulation was not directly through the $\beta$ catenin pathway, but most likely indirectly through upregulation of c-Myc which is a target gene of the Wnt pathway. HDAC2 is required for and sufficient on its own to prevent apoptosis of colonic cancer cells, and interference with HDAC 2 by valproic acid largely diminished adenoma formation in APC min mice.

GSK3 $\beta$ inhibitors can be divided into several groups: (1) the non-selective GSK3 $\beta$ inhibitors, such as lithium and valproic acid; (2) the ATP-competitive inhibitors, which can be divided in several classes according to their chemical structure [132]; and (3) the non-ATPcompetitors such as small thiadiazolidinones derivatives, the first non-ATP competitive GSK3 $\beta$ inhibitors reported to date [133]. A detailed description of the different GSK $3 \beta$ inhibitors is beyond the scope of this review, for more information on the different classes, we refer to [134-136]. Only Lithium and Valproic acid are discussed here because many studies have demonstrated their effect on the Wnt signaling pathway.

Lithium has been shown to be a non-specific reversible inhibitor of GSK3 $\beta$ with an $\mathrm{IC}_{50}$ value of $2 \mathrm{mM}$ [137]. Recently, it was reported that the response to lithium occurs via two levels of inhibition: a rapid, direct inhibition of GSK $3 \beta$ by competing for $\mathrm{Mg}^{2+}$, followed by the inactivation of Protein Phosphatase 1 and subsequent increased inhibitory phosphorylation of GSK3 $\beta$ [138]. These two inhibitory actions following exposure to lithium probably act together in vivo to achieve an increased inhibition of GSK3 $\beta$ [139]. Signal transduction systems known to be perturbed by lithium involve phosphoinositide (PI) turnover, activation of the Wnt pathway via inhibition of GSK3 $\beta$, and a growth factor-induced, Akt-mediated signal that promotes cell survival. These pathways, acting in synergy, probably lead to the amplification of the lithium signal. Because of the functions of GSK $3 \beta$ in many different signaling pathways and diseases (diabetes, Alzheimer's disease, mood disorders, inflammatory signaling and cancer), it is likely that lithium can have therapeutic effects in all these diseases, but the possibility of unwanted side-effects will also increase.

Valproic acid (VPA, 2-propylpentanoic acid) like lithium, is an established drug. During the past years, it has become evident that VPA is also associated with anti-cancer activity. VPA not only suppresses tumor growth and metastasis, but also induces tumor differentiation in vitro and in vivo. Several mechanisms of ac- 
tion might be relevant for the biological activity of VPA: (1) VPA increases the DNA binding ability of activating protein-1 (AP-1) transcription factor, and the expression of genes regulated by the extracellular-regulated kinase (ERK)-AP-1 pathway; (2) VPA downregulates protein kinase C (PKC) activity; (3) VPA inhibits GSK3 $\beta$, a negative regulator of the Wnt signaling pathway; (4) VPA activates the peroxisome proliferator-activated receptors PPAR $\gamma$ and $\delta$; and (5) VPA blocks HDAC [140]. VPA may thus exert its function on Wnt signaling through inhibition of GSK3 $\beta$ and/or inhibition of HDAC [141, 142].

Gleevec $^{\circledR}$, (Glivec, imatinib mesylate, STI571), although originally identified as platelet derived growth factor (PDGF) receptor inhibitor, and developed as an inhibitor of the constitutively active Bcr-Abl kinase, is also able to inhibit the c-kit tyrosine kinase. It is conceivable that other tyrosine kinases may also serve as possible cellular targets of Gleevec, especially when higher concentrations of Gleevec are used [143]. Gleevec has recently been approved for the treatment of chronic myeloid leukemia and gastrointestinal tumors [143]. $\beta$-catenin is a tyrosine phosphorylated protein and some growth factors (such as HGF, IGF-1 and IGF-2) may play a role in regulating $\beta$-catenin signaling activity. Gleevec has been shown to effectively inhibit the constitutive activity of $\beta$-catenin signaling in human colon cancer cells (HCT-116 and SW480) as well as in Wnt1 induced activation of $\beta$-catenin signaling in different cell lines [143]. Furthermore, Gleevec was shown to effectively suppress the proliferation of these human colon cancer cells. The current prevailing hypothesis is that tyrosine phosphorylation of the $\beta$-catenin protein would result in decreased association with E-cadherin, leading to the disruption of junctional assembly and an increased tendency for cancer cells to become invasive and metastasize [143]. Tyrosine phosphorylation may thus play an important role in regulating $\beta$-catenin signaling activity, and inhibition of this signaling pathway by Gleevec may be further explored as an important target for alternative/adjuvant treatments for different types of cancer.

Flavonoids comprise the most common group of plant polyphenols and provide much of the flavor and color to fruits and vegetables [144]. More than 5000 different flavonoids have been described, and they are divided into 6 subclasses. Yang and colleagues have recently published several articles on the effect of different flavonoids, such as quercetin, naringenin and flavanone, on $\beta$-catenin/Tcf signaling using in vitro assays [145147]. Their data suggest that the different flavonoids tested inhibit $\beta$-catenin/Tcf signaling efficiently although a common mechanism by which flavonoids inhibit Tcf activity remains to be established. The large amount of studies on flavonoids exemplifies the interest in the biological properties of natural products as a means to iden- tify novel small molecular weight compounds that could have potential as therapeutic. Because different studies have reported contrasting observations ranging from a protective effect of flavonoid consumption in cardiovascular disease and cancer to potential harm, it would be imperative to have a thorough understanding of the different mechanisms of action whereby flavonoids might act in different tumor and normal cell types. In vitro studies such as those reported by Park et al. are important in the determination of the potential of a compound as a chemotherapeutic agent. This group has recently also shown that ionomycin inhibits $\beta$-catenin/Tcf signaling in colon cancer cells [148].

\section{Drug design strategies for the Wnt-dependent signaling pathways in cancer}

Many components of the Wnt-dependent signaling pathways may represent targets for future drug discovery efforts. As previously described, the initial step in Wntdependent signaling is the interaction between Wnt and Fzd. Cancer cell growth may be inhibited by an agent that would selectively inhibit the binding of the Wnt protein with its Fzd receptor or which would upregulate the expression of endogenous antagonists such as sFRP, WIF-1, Cerberus or DKK. This agent could be an antibody that specifically binds to a Wnt protein, or a Fzd receptor to disrupt the binding between ligand and receptor. It has recently been demonstrated that anti-Wnt 2 antibodies can induce apoptosis in human cancer cells [53, 54]. These antibodies showed no detectable effect on normal cell lines, suggesting anti-Wnt2 antibody could specifically induce apoptosis in cancer cells, whilst sparing normal cells. Anti-Wnt antibodies may not only directly induce apoptosis in cancer cells that overexpress Wnt proteins, but also counter potential drug resistance by restoring the normal apoptotic machinery in these tumor cells [52]. A potential hurdle that antibody-based therapies could face is the epitope accessibility in the tumor.

Although ligand-receptor interactions are heavily targeted in drug discovery, the ligand-receptor interaction in the Wnt signaling pathway is not as straightforward as for other pathways. Of the entire Wnt signaling pathway, least is known about the ligand-receptor interaction. One major barrier hampering the understanding of this has been the difficulty in obtaining soluble and biologically active Wnt proteins. With the recent success by Willert et al. in purifying Wnt3a [149], and elucidating the chemical basis for the uncooperative property of Wnt proteins, this hurdle has been overcome. The second problem is the specificity of Wnt/Fzd interactions. As indicated previously, the Wnt family consists of at least 19 members (http://www.stanford.edu/ rnusse/wntwindow.html) who all share a conserved pattern of 23 or 24 
cysteine residues, several asparagine-linked glycosylation sites and a length of 350 to 400 amino acids [150]. The Fzd family consists of 10 members (http://www.stanford.edu/ rnusse/wntwindow.html).

Structurally, Fzd receptors are similar to other seven-pass transmembrane proteins such as $G$-protein coupled receptors (GPCRs), but the actual signaling through a $G$-protein has only been observed in a few cases. Direct binding with full-length Fzd has been demonstrated for only a few Wnt proteins, including Wg and XWnt8 $[151,152]$. These in vitro binding experiments showed that a single Wnt can bind to several Fzd proteins, including homologous members from a different species. A more comprehensive assessment of the interactions between various Wnt/Fzd pairs remains to be conducted. The promiscuous binding pattern observed with some Wnt and Fzd members raises the possibility that there may be considerable redundancy in ligand-receptor interactions [151-153]. The fact that Fzd receptors are putative GPCRs makes it a more interesting target. It has been estimated that $50 \%$ of all modern drugs and almost one-quarter of the top-selling drugs in the year 2000 modulated GPCR activity [154]. This reflects the expertise many pharmaceutical companies have on GPCR drug design. However, despite the past success of drug development on GPCRs, current efforts to bring further classes of GPCR-targeted drugs through the pipeline are proving less productive than might have been predicted. This is in spite of the accumulated knowledge on GPCRs. This has led to a change in the way drug discovery is being approached. The emphasis of GPCR-directed drug discovery is shifting from a traditional focus on biogenic monoamine receptors, which have natural ligands that are readily amenable to chemical modification to produce lead compounds, to a more recent focus on peptide-activated receptors, which present an entirely different type of synthetic challenge to the drug discovery community. The Wnt/Fzd interaction is one such example of a peptide-receptor interaction, and thus may be a reason for avoiding this interaction as a drug target, until more is known about these types of interactions. The third problem is the co-receptor. The $\beta$-catenin pathway requires an additional single-pass transmembrane protein, known as LRP5 and LRP6 from the low-density-lipoprotein (LDL) receptor family, to function as an obligate co-receptor for transducing the Wnt signal [9-11]. This adds another level of complexity as different receptor and co-receptor combinations can result in the transduction of signals down different pathways. LRPs are single transmembrane proteins that contain epidermal growth factor like repeats and three LDL-receptor type Q repeats in their extracellular region [155]. Intracellularly, these proteins contain a prolinerich region that are predicted to bind to $\mathrm{SH} 3$ domain containing proteins. It appears that these co-receptors associate with Fzd in a Wnt-dependent fashion [10]. It is not yet clear how these complexes are organized; they may be heterotrimeric complexes of LRP, Fzd and Wnt, or heterodimeric complexes of just Fzd and LRP. It may also be that these proteins are important intracellularly, bridging Fzd and Dvl, or Fzd and other signaling molecules such as SH3 domain containing proteins. The function of the LRP co-receptors appears to be tightly connected to their Fzd/Wnt-related functions since knocking out these proteins mimics a combination of Wnt knockout phenotypes [44]. These observations make the Wnt/Fzd interaction a very difficult target for small molecule inhibitors, additional to the fact that peptide interactions are inherently more difficult targets to modulate.

Following activation of the Fzd receptor, the unequivocal identification of the downstream signaling mechanism remains to be unraveled. One hypothetical pathway leads to Dvl activation. Data suggest that Dvl proteins organize dynamic, pathway-specific subcellular signaling complexes that ensure correct information routing, signal amplification, and dynamic control through feedback regulation [156]. Interrupting the Fzd-Dvl interaction could serve as a powerful tool to dissect the molecular mechanism underlying the Wnt pathways. Furthermore, it could interfere with specific Wnt signaling events that contribute to cancer and other human diseases.

There is evidence that the multiprotein $\beta$-catenin destruction complex could turn out to be a relatively good drug target. Of the components of the complex (Axin, APC, $\beta$-catenin and GSK $3 \beta$ ), GSK $3 \beta$ is the best validated target, due to its implication in the pathophysiology of numerous other diseases, including Alzheimer's disease, diabetes, and bipolar disorder [157, 158]. Originally identified as a modulator of glycogen metabolism, GSK3 is now understood to play an important role in a variety of pathways including initiation of protein synthesis, cell proliferation, cell differentiation, apoptosis, and is essential in embryonic development as a component of the Wnt signaling cascade. GSK3 can be considered as a target for both metabolic and neurological disorders. However, a major concern is that since this protein is involved in so many pathways and diseases, compounds targeting this protein for its function in one pathway (and linked disease) will alter its function in another pathway and potentially give rise to serious side effects (on-target side effects). For instance, lithium described as a nonselective GSK3 $\beta$ inhibitor is used for treatment of bipolar disorder as well as in cancer research, to activate the Wnt signaling pathway as a model for carcinogenesis. It is thus of considerable importance to determine if GSK $3 \beta$ inhibitors also have a tumorigenic effect. Gould et al. recently investigated the effects of lithium in a murine 
model predisposed to the formation of tumors due to activation of the Wnt pathway (the APC multiple intestinal neoplasia (min) mouse) [159]. They found that 60 days of lithium treatment did not produce a significant increase in the number of tumors in these genetically predisposed mice, it only resulted in a modest overall increase in the tumor size [159]. These results suggest that lithium, which has been prescribed for more than 50 years, and by extension perhaps other inhibitors of GSK3, pose a low risk for the development of cancers. This is entirely consistent with the available epidemiological evidence that long term lithium therapy does not increase cancer morbidity or mortality. Furthermore, other mechanisms independent of phosphorylation by GSK 3 can contribute to $\beta$-catenin degradation indicating a redundancy in mechanisms leading to $\beta$-catenin degradation. Recent crystal structures, including the active (phosphorylated Tyr-216) form of GSK $3 \beta$, provided a wealth of structural information and greater understanding of GSK3's unique regulation and substrate specificity [160].

As stated previously, activation of $\beta$-catenin is a critical step in the pathogenesis of many common human cancers and is the initiating event in adenocarcinoma of the colon [161]. Oncogenes such as $\beta$-catenin represent (in theory) extremely attractive molecular targets for the development of anticancer compounds as specific pharmacological inhibition of activated $\beta$-catenin might reverse the tumorigenic properties of human cancer cells and therefore form the basis of an effective anticancer strategy [161]. Recently, proof of principle was shown when small interfering RNAs (siRNAs) directed against $\beta$-catenin inhibited the in vitro and in vivo growth of colon cancer cells. These siRNAs ultimately may have the potential as a therapeutic modality to treat cancer $[162,163]$. $\beta$-catenin has diverse functions as an essential component of intercellular junctions and the Wnt signaling pathway and has therefore numerous different binding partners (Figure 2).

The interaction of $\beta$-catenin with Lef/Tcf transcription factors is seen as one of the crucial events. Over- expression of dominant negative Tcf4 in colorectal tumor cells causes cells to arrest in the $\mathrm{G}_{1}$ phase of the cell cycle supporting the relevance of Tcf4 in colorectal tumor cell proliferation [164]. Several studies have shown that inhibition of the initiating transforming event in colorectal cancer cell lines, i.e., the inappropriate formation of a $\beta$-catenin/Tcf complex, drives these cells out of the cycle [164]. Tcf4 inhibition induced colorectal cancer cells to differentiate into a villus epithelial phenotype, essentially completing their life cycle after many years delay [165]. Tcf4 has recently been identified as a transcriptional target of p53 signaling. Induction of p53 leads to a reduction of Tcf4 mRNA and protein [166], and thus acts to decrease the $\mathrm{Wnt} / \beta$-catenin signaling activity. Hence, the accumulated data make a strong argument to consider the $\beta$-catenin/Tcf 4 complex a promising target for therapeutic intervention in cancer. Small molecular weight inhibitors of this interaction might therefore be expected to have anti-tumorigenic effects.

Lepourcelet et al. have explored high-throughput screening of compound libraries in search for small molecule inhibitors of the Wnt cascade [167]. Out of approximately 7,000 natural compounds, 8 displayed reproducible and dose-dependent inhibition of the protein-protein interaction between $\beta$-catenin and Tcf4 in an immunoenzymatic assay with $\mathrm{IC}_{50}$ values lower than $10 \mu \mathrm{M}$ (Figure 3). Six compounds were evaluated in a range of in vitro secondary assays such as reporter gene activation, expression analysis, cell proliferation, and Xenopus duplication assay. Three compounds (PKF115584, CGP049090, and PKF222-815), with the same chemical core structure, scored consistently in the different assays (surface plasmon resonance, reporter gene assays, GST-pulldown assay, electrophoretic mobility shift assay) used to confirm the antagonistic properties of the compounds. Initial reports from Lepourcelet et al. show that the classical approach of high throughput screening in a cell-free assay can yield protein interaction inhibitors that retain their effects when tested in cell-based assays [167]. A search of the patent literature indicates that

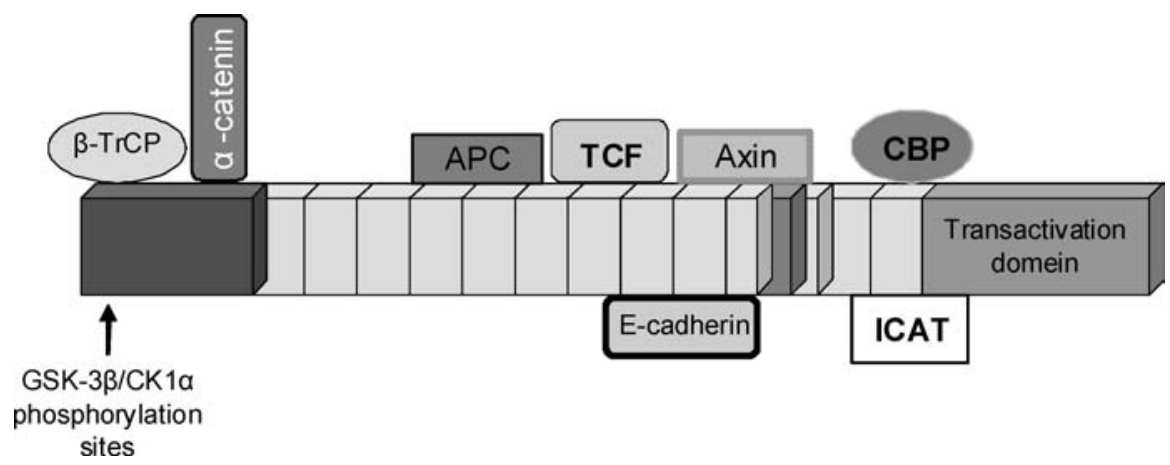

Figure 2. Interaction sites for binding partners of $\beta$-catenin (from http://www.stanford.edu/ rnusse/wntwindow.html). 
several other groups are studying compounds and methods for modulating $\beta$-catenin mediated gene expression. For instance, Blaschuk et al. described several peptide sequences capable of affecting the interaction between $\beta$-catenin and transcription factors [168], while Moll et al. identified a compound which is able to interact with $\beta$-catenin/Tcf4 [169]. The difference in binding affinity of Tcf4 to $\beta$-catenin in the presence of an inhibitor was determined through Isothermal Titration $\mu$-Calorimetry (ITC). The identified compound reduced Tcf4 affinity for $\beta$-catenin about 10 -fold. NMR screening, which is particularly suited for the identification of protein-protein interaction antagonists confirmed that the compound is an antagonist of the $\beta$-catenin/Tcf4 interaction.

More recently, a patent and subsequent publication by Kahn et al., disclosed the preparation and biological evaluation of a series of compounds able to block the $\beta$ catenin/Tcf4 transcriptional pathway by inhibiting cyclic AMP response element-binding protein (CBP) (Figure 4) $[70,171]$. CBP or its closely related homolog p300 were initially identified in protein interaction assays, first through their association with the transcription factor CREB [172] and later through their interaction with the adenoviral-transforming protein E1A [173]. CBP had the potential to participate in a variety of cellular functions including transcriptional coactivator function [174]. $\mathrm{CBP} / \mathrm{p} 300$ potentiates $\beta$-catenin mediated activation [20]. $\beta$-catenin interacts directly with the CREB-binding domain of $\mathrm{CBP}$ and $\beta$-catenin synergizes with $\mathrm{CBP}$ to stimulate the transcriptional activation of $\beta$-catenin/Tcf4 [175]. The compound (ICG-001; Figure 4) described by Kahn et al. showed specific affinity and inhibition of $\mathrm{CBP}$, and proved effective in preventing CBP-mediated transcriptional activation and $\beta$-catenin/Tcf4 transcription in luciferase reporter gene assays. ICG-001 induced apoptosis in SW480 colon cancer cells in a concentration dependent manner, but not in normal colonic epithelial cells and inhibited the growth of SW480 cells with an $\mathrm{IC}_{50}$ value of $8.07 \mu \mathrm{M}$. They also demonstrated that ICG-001 was efficacious in both the Min mouse and nude mouse SW620 xenograft models of cancer [170]. Mapping studies demonstrated that the interacting domains of both CBP and p300 with the C-terminus of $\beta$-catenin reside within the $\mathrm{N}$-terminal 110 residues of the co-activators. Interestingly, this region also contains the $\mathrm{CBP} / \mathrm{p} 300$-binding site for retinoic acid (RA) receptors, RXR/RAR [176]. It has been shown that RA treatment inhibits $\beta$-catenin/Tcf-mediated transcription [177].

Ultimately, the above described compounds could become novel anticancer drugs. These compounds certainly have considerable potential as tools for the investigation of $\beta$-catenin dependent cellular pathways. They also clearly show the feasibility of targeting protein-protein

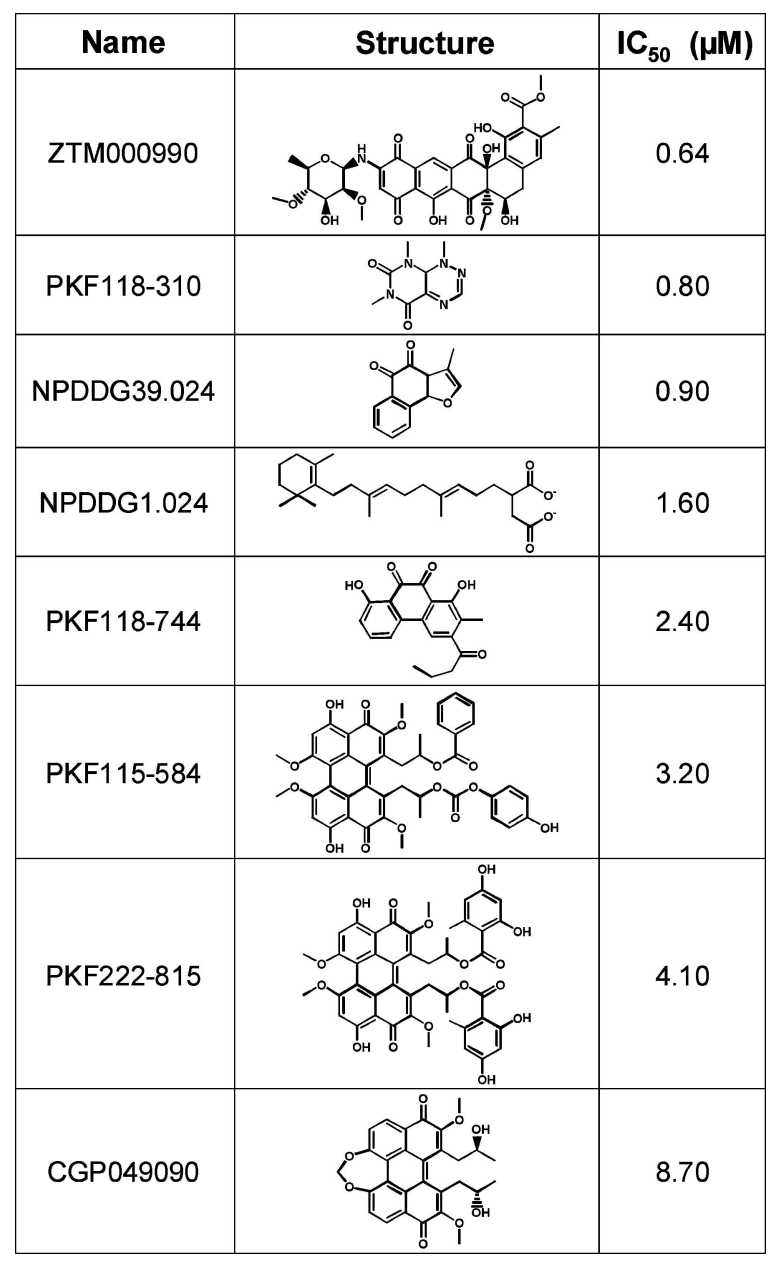

Figure 3. Lead structures for Wnt signaling pathway inhibitors.

\section{ICG-001}<smiles>O=C1[C@@H](Cc2ccc(O)cc2)N2C(=O)CCN(C(=O)NCc3ccccc3)[C@H]2CN1Cc1cccc2ccccc12</smiles>

Figure 4. Chemical structure of ICG-001.

interactions in cancer drug discovery. The $\beta$-catenin/Tcf complex is thus an attractive target for anti-cancer drugs, but any such compound must selectively interfere with the complex without disrupting other essential interactions of $\beta$-catenin [178].

The design of compounds targeting the $\beta$-catenin/Tcf interaction depends on a detailed understanding of the interactions of $\beta$-catenin with its other interaction partners. The interaction between Tcf transcription factors and $\beta$ - 
catenin requires a minimal $\mathrm{N}$-terminal Tcf fragment and the central domain of 12 armadillo repeats in $\beta$-catenin $[179,180]$. Disrupting the E-cadherin binding has been implicated in the transition form adenoma to carcinoma, suggesting that the adhesive role of $\beta$-catenin is likely to be crucial for suppressing tumor growth and metastasis. Disrupting the interaction of $\beta$-catenin with APC or Axin would also have undesirable consequences, as it would lead to a larger pool of free $\beta$-catenin by inhibiting $\beta$-catenin degradation. Increasing concentrations of the drug would then be required to inhibit the $\beta$-catenin/Tcf interaction. The compounds shown in Figure 3 that have been described as $\beta$-catenin/Tcf4 antagonists also disrupt cellular $\beta$-catenin/APC complexes [167] supporting the speculation that pharmacological interference with $\beta$ catenin complexes may be inherently unselective $[180$ 182]. The $\beta$-catenin/Tcf complex is an enticing target for rational design of cancer therapeutics, but the promiscuity of $\beta$-catenin makes it clear that this strategy will not be easy. More detailed thermodynamic and structural data on ligand recognition by $\beta$-catenin and insights obtained from the crystal structures of $\beta$-catenin/Tcf [183, 184] and alternative protein complexes should aid this process. But the results by Emami et al. have shown that targeting alternative mechanisms to inhibit a subset of $\beta$-catenin/Tcf-mediated transcription can enhance the selectivity of the compounds [170].

Given that the Wnt signaling pathway is implicated in a substantial number of diseases, and given that a number of mutations lead to the activation of this pathway and cancer in several tissues, there is a clear need for drugs that attenuate the nuclear functions of $\beta$-catenin. Future development of both peptide and non-peptide based inhibitors of components of the Wnt signaling pathway, combined with further elucidation of mechanisms of action will undoubtedly result in the generation of more potent and specific inhibitors of Wnt signaling. These inhibitors may provide significant therapeutic benefit against a variety of human diseases in which the Wnt signaling pathway plays an important pathological role.

In conclusion, we have discussed the many opportunities that lie within the Wnt signaling pathway to be used as targets in oncology drug discovery. In addition, the small molecule inhibitors of the Wnt signaling pathway that have been discussed here could clear the path for large scale screens to discover specific inhibitors that target components or mechanisms in the Wnt-dependent signaling pathways.

\section{References}

1. Du SJ, Purcell SM, Christian JL, McGrew LL, Moon RT: Identification of distinct classes and functional domains of Wnts through expression of wild-type and chimeric proteins in Xenopus embryos. Mol Cell Biol 15:2625-2634, 1995

2. Wodarz A, Nusse R: Mechanisms of Wnt signaling in development. Annual Review of Cell \& Developmental Biology 14:59-88, 1998

3. Wong GT, Gavin BJ, McMahon AP: Differential transformation of mammary epithelial cells by Wnt genes. Mol Cell Biol 14:62786286, 1994

4. Moon RT, DeMarais A, Olson DJ: Responses to Wnt signals in vertebrate embryos may involve changes in cell adhesion and cell movement. J Cell Sci Suppl 17:183-188, 1993

5. Kuhl M: Non-canonical Wnt signaling in Xenopus: regulation of axis formation and gastrulation. Semin Cell Dev Biol 13:243-249, 2002

6. He X, Saint-Jeannet JP, Wang Y, Nathans J, Dawid I, Varmus H: A member of the Frizzled protein family mediating axis induction by Wnt-5A. Science 275:1652-1654, 1997

7. Vincan E: Frizzled/WNT signalling: the insidious promoter of tumour growth and progression. Front Biosci 9:1023-1034, 2004

8. Kawano Y, Kypta R: Secreted antagonists of the Wnt signalling pathway. J Cell Sci 116:2627-2634, 2003

9. Pinson KI, Brennan J, Monkley S, Avery BJ, Skarnes WC: An LDL-receptor-related protein mediates Wnt signalling in mice. Nature 407:535-538, 2000

10. Tamai K, Semenov M, Kato Y, Spokony R, Liu CM, Katsuyama Y, Hess F, Saint-Jeannet JP, He X: LDL-receptor-related proteins in Wnt signal transduction. Nature 407:530-535, 2000

11. Wehrli M, Dougan ST, Caldwell K, O'Keefe L, Schwartz S, VaizelOhayon D, Schejter E, Tomlinson A, DiNardo S: Arrow encodes an LDL-receptor-related protein essential for Wingless signalling. Nature 407:527-530, 2000

12. Carron C, Pascal A, Djiane A, Boucaut JC, Shi DL, Umbhauer M: Frizzled receptor dimerization is sufficient to activate the Wnt/beta-catenin pathway. J Cell Sci 116:2541-2550, 2003

13. Schweizer L, Varmus H: Wnt/Wingless signaling through betacatenin requires the function of both LRP/Arrow and frizzled classes of receptors. BMC Cell Biol 4:4, 2003

14. Ding Y, Dale T: Wnt signal transduction: kinase cogs in a nanomachine? Trends Biochem Sci 27:327-329, 2002

15. Staal FJ, Noort MM, Strous GJ, Clevers HC: Wnt signals are transmitted through $\mathrm{N}$-terminally dephosphorylated beta-catenin. EMBO Rep 3:63-68, 2002

16. Clevers $\mathrm{H}$, van de Wetering M: TCF/LEF factor earn their wings. Trends Genet 13:485-489, 1997

17. Hurlstone A, Clevers H: T-cell factors: turn-ons and turn-offs. EMBO J 21:2303-2311, 2002

18. Roose J, Clevers H: TCF transcription factors: molecular switches in carcinogenesis. Biochimica et Biophysica Acta 1424:M23M37, 1999

19. Van de Wetering M., Cavallo R, Dooijes D, van Beest M, van Es J, Loureiro J, Ypma A, Hursh D, Jones T, Bejsovec A, Peifer M, Mortin M, Clevers H: Armadillo coactivates transcription driven by the product of the Drosophila segment polarity gene dTCF. Cell 88:789-799, 1997

20. Hecht A, Vleminckx K, Stemmler MP, van Roy F, Kemler R: The $\mathrm{p} 300 / \mathrm{CBP}$ acetyltransferases function as transcriptional coactivators of beta-catenin in vertebrates. EMBO J 19:1839-1850, 2000

21. Cavallo RA, Cox RT, Moline MM, Roose J, Polevoy GA, Clevers H, Peifer M, Bejsovec A: Drosophila Tcf and Groucho interact to repress Wingless signalling activity. Nature 395:604-608, 1998

22. Roose J, Molenaar M, Peterson J, Hurenkamp J, Brantjes H, Moerer P, van de WM, Destree O, Clevers H: The Xenopus Wnt 
effector XTcf-3 interacts with Groucho-related transcriptional repressors. Nature 395:608-612, 1998

23. Waltzer L, Bienz M: The control of beta-catenin and TCF during embryonic development and cancer. Cancer \& Metastasis Reviews 18:231-246, 1999

24. Kuhl M, Sheldahl LC, Park M, Miller JR, Moon RT: The $\mathrm{WNT} / \mathrm{Ca} 2+$ pathway, a new vertebrate Wnt signaling pathway takes shape. Trends Genet 16:279-283, 2000

25. Slusarski DC, Yang-Snyder J, Busa WB, Moon RT: Modulation of embryonic intracellular Ca2+ signaling by Wnt-5A. Dev Biol 182:114-120, 1997

26. Sheldahl LC, Park M, Malbon CC, Moon RT: Protein kinase C is differentially stimulated by Wnt and Frizzled homologs in a G-protein-dependent manner. Curr Biol 9:695-698, 1999

27. Kuhl M, Sheldahl LC, Malbon CC, Moon RT: $\mathrm{Ca}(2+) /$ calmodulindependent protein kinase II is stimulated by Wnt and Frizzled homologs and promotes ventral cell fates in Xenopus. J Biol Chem 275:12701-12711, 2000

28. Saneyoshi T, Kume S, Amasaki Y, Mikoshiba K: The Wnt/calcium pathway activates NF-AT and promotes ventral cell fate in Xenopus embryos. Nature 417:295-299, 2002

29. Westfall TA, Brimeyer R, Twedt J, Gladon J, Olberding A, Furutani-Seiki M, Slusarski DC: Wnt-5/pipetail functions in vertebrate axis formation as a negative regulator of $\mathrm{Wnt} /$ beta-catenin activity. J Cell Biol 162:889-898, 2003

30. Liu XX, Liu T, Slusarski DC, Yang-Snyder J, Malbon CC, Moon RT, Wang HY: Activation of a Frizzled-2/beta-adrenergic receptor chimera promotes Wnt signaling and differentiation of mouse F9 teratocarcinoma cells via $\mathrm{G}$ alpha $\mathrm{o}$ and $\mathrm{G}$ alpha t. Proceedings of the National Academy of Sciences of the United States of America 96:14383-14388, 1999

31. Torres MA, Yang-Snyder JA, Purcell SM, DeMarais AA, McGrew LL, Moon RT: Activities of the Wnt-1 class of secreted signaling factors are antagonized by the Wnt-5A class and by a dominant negative cadherin in early Xenopus development. J Cell Biol 133:1123-1137, 1996

32. Ishitani $\mathrm{T}$, Kishida $\mathrm{S}$, Hyodo-Miura $\mathrm{J}$, Ueno $\mathrm{N}$, Yasuda J, Waterman M, Shibuya H, Moon RT, Ninomiya-Tsuji J, Matsumoto K: The TAK1-NLK mitogen-activated protein kinase cascade functions in the Wnt $-5 \mathrm{a} / \mathrm{Ca}(2+)$ pathway to antagonize Wnt/beta-catenin signaling. Mol Cell Biol 23:131-139, 2003

33. Kuhl M, Geis K, Sheldahl LC, Pukrop T, Moon RT, Wedlich D: Antagonistic regulation of convergent extension movements in Xenopus by Wnt/beta-catenin and Wnt/Ca2 + signaling. Mech Dev 106:61-76, 2001

34. Mlodzik M: Planar cell polarization: do the same mechanisms regulate Drosophila tissue polarity and vertebrate gastrulation? Trends Genet 18:564-571, 2002

35. Tree DR, Ma D, Axelrod JD: A three-tiered mechanism for regulation of planar cell polarity. Semin Cell Dev Biol 13:217-224, 2002

36. Habas R, Dawid IB, He X: Coactivation of Rac and Rho by Wnt/Frizzled signaling is required for vertebrate gastrulation. Genes Dev 17:295-309, 2003

37. Dabdoub A, Donohue MJ, Brennan A, Wolf V, Montcouquiol M, Sassoon DA, Hseih JC, Rubin JS, Salinas PC, Kelley MW: Wnt signaling mediates reorientation of outer hair cell stereociliary bundles in the mammalian cochlea. Development 130:2375-2384, 2003

38. Djiane A, Riou J, Umbhauer M, Boucaut J, Shi D: Role of frizzled 7 in the regulation of convergent extension movements during gastrulation in Xenopus laevis. Development 127:3091-3100, 2000

39. Tada M, Concha ML, Heisenberg CP: Non-canonical Wnt sig- nalling and regulation of gastrulation movements. Semin Cell Dev Biol 13:251-260, 2002

40. Nusse R, Varmus HE: Many tumors induced by the mouse mammary tumor virus contain a provirus integrated in the same region of the host genome. Cell 31:99-109, 1982

41. Polakis P: Wnt signaling and cancer. Genes Dev 14:1837-1851, 2000

42. Giles RH, van Es JH, Clevers H: Caught up in a Wnt storm: Wnt signaling in cancer. Biochim Biophys Acta 1653:1-24, 2003

43. Lustig B, Behrens $\mathrm{J}$ : The Wnt signaling pathway and its role in tumor development. J Cancer Res Clin Oncol 129:199-221, 2003

44. Morin PJ, Weeraratna AT: Wnt signaling in human cancer. Cancer Treat Res 115:169-187, 2003

45. Gunther EJ, Moody SE, Belka GK, Hahn KT, Innocent N, Dugan KD, Cardiff RD, Chodosh LA: Impact of p53 loss on reversal and recurrence of conditional Wnt-induced tumorigenesis. Genes Dev 17:488-501, 2003

46. Lane TF, Leder P: Wnt-10b directs hypermorphic development and transformation in mammary glands of male and female mice. Oncogene 15:2133-2144, 1997

47. Huguet EL, McMahon JA, McMahon AP, Bicknell R, Harris AL: Differential expression of human Wnt genes 2, 3, 4, and 7B in human breast cell lines and normal and disease states of human breast tissue. Cancer Res 54:2615-2621, 1994

48. Smalley MJ, Dale TC: Wnt signaling and mammary tumorigenesis. J Mammary Gland Biol Neoplasia 6:37-52, 2001

49. Holcombe RF, Marsh JL, Waterman ML, Lin F, Milovanovic T, Truong T: Expression of Wnt ligands and Frizzled receptors in colonic mucosa and in colon carcinoma. Mol Pathol 55:220-226, 2002

50. Howe LR, Brown AM: Wnt signaling and breast cancer. Cancer Biol Ther 3:36-41, 2004

51. Weeraratna AT, Jiang Y, Hostetter G, Rosenblatt K, Duray P, Bittner M, Trent JM: Wnt5a signaling directly affects cell motility and invasion of metastatic melanoma. Cancer Cell 1:279-288, 2002

52. Chen S, Guttridge DC, You Z, Zhang Z, Fribley A, Mayo MW, Kitajewski J, Wang CY: Wnt-1 Signaling Inhibits Apoptosis by Activating beta-Catenin/T Cell Factor-mediated Transcription. J Cell Biol 152:87-96, 2001

53. You L, He B, Xu Z, Uematsu K, Mazieres J, Mikami I, Reguart N, Moody TW, Kitajewski J, McCormick F, Jablons DM: Inhibition of Wnt-2-mediated signaling induces programmed cell death in non-small-cell lung cancer cells. Oncogene 2004

54. You L, He B, Xu Z, Uematsu K, Mazieres J, Fujii N, Mikami I, Reguart N, McIntosh JK, Kashani-Sabet M, McCormick F, Jablons DM: An anti-Wnt-2 monoclonal antibody induces apoptosis in malignant melanoma cells and inhibits tumor growth. Cancer Res 64:5385-5389, 2004

55. Stoehr R, Wissmann C, Suzuki H, Knuechel R, Krieg RC, Klopocki E, Dahl E, Wild P, Blaszyk H, Sauter G, Simon R, Schmitt R, Zaak D, Hofstaedter F, Rosenthal A, Baylin SB, Pilarsky C, Hartmann A: Deletions of chromosome 8p and loss of sFRP1 expression are progression markers of papillary bladder cancer. Lab Invest 84:465-478, 2004

56. Ko J, Ryu KS, Lee YH, Na DS, Kim YS, Oh YM, Kim IS, Kim JW: Human secreted frizzled-related protein is down-regulated and induces apoptosis in human cervical cancer. Exp Cell Res 280:280-287, 2002

57. Ugolini F, Charafe-Jauffret E, Bardou VJ, Geneix J, Adelaide J, Labat-Moleur F, Penault-Llorca F, Longy M, Jacquemier J, Birnbaum D, Pebusque MJ: WNT pathway and mammary carcinogenesis: Loss of expression of candidate tumor suppressor gene SFRP1 in most invasive carcinomas except of the medullary type. 
Oncogene 20:5810-5817, 2001

58. To KF, Chan MW, Leung WK, Yu J, Tong JH, Lee TL, Chan FK, Sung JJ: Alterations of frizzled (FzE3) and secreted frizzled related protein (hsFRP) expression in gastric cancer. Life Sci 70:483-489, 2001

59. Caldwell GM, Jones C, Gensberg K, Jan S, Hardy RG, Byrd P, Chughtai S, Wallis Y, Matthews GM, Morton DG: The Wnt antagonist sFRP1 in colorectal tumorigenesis. Cancer Res 64:883888,2004

60. Suzuki H, Gabrielson E, Chen W, Anbazhagan R, van Engeland M, Weijenberg MP, Herman JG, Baylin SB: A genomic screen for genes upregulated by demethylation and histone deacetylase inhibition in human colorectal cancer. Nat Genet 31:141-149, 2002

61. Suzuki H, Watkins DN, Jair KW, Schuebel KE, Markowitz SD, Dong CW, Pretlow TP, Yang B, Akiyama Y, van Engeland M, Toyota M, Tokino T, Hinoda Y, Imai K, Herman JG, Baylin SB: Epigenetic inactivation of SFRP genes allows constitutive WNT signaling in colorectal cancer. Nat Genet 36:417-422, 2004

62. Wissmann C, Wild PJ, Kaiser S, Roepcke S, Stoehr R, Woenckhaus M, Kristiansen G, Hsieh JC, Hofstaedter F, Hartmann A, Knuechel R, Rosenthal A, Pilarsky C: WIF1, a component of the Wnt pathway, is down-regulated in prostate, breast, lung, and bladder cancer. J Pathol 201:204-212, 2003

63. Mazieres J, He B, You L, Xu Z, Lee AY, Mikami I, Reguart N, Rosell R, McCormick F, Jablons DM: Wnt inhibitory factor-1 is silenced by promoter hypermethylation in human lung cancer. Cancer Res 64:4717-4720, 2004

64. Kirikoshi H, Sekihara H, Katoh M: Up-regulation of Frizzled-7 (FZD7) in human gastric cancer. Int J Oncol 19:111-115, 2001

65. Rhee CS, Sen M, Lu D, Wu C, Leoni L, Rubin J, Corr M, Carson DA: Wnt and frizzled receptors as potential targets for immunotherapy in head and neck squamous cell carcinomas. Oncogene 21:6598-6605, 2002

66. Sagara N, Toda G, Hirai M, Terada M, Katoh M: Molecular cloning, differential expression, and chromosomal localization of human frizzled-1, frizzled-2, and frizzled-7. Biochem Biophys Res Comm 252:117-122, 1998

67. Terasaki H, Saitoh T, Shiokawa K, Katoh M: Frizzled-10, upregulated in primary colorectal cancer, is a positive regulator of the. Int J Mol Med 9:107-112, 2002

68. Hoang BH, Kubo T, Healey JH, Sowers R, Mazza B, Yang R, Huvos AG, Meyers PA, Gorlick R: Expression of LDL receptorrelated protein 5 (LRP5) as a novel marker for disease progression in high-grade osteosarcoma. Int J Cancer 109:106-111, 2004

69. Gong Y, Slee RB, Fukai N, Rawadi G, Roman-Roman S, Reginato AM, Wang H, Cundy T, Glorieux FH, Lev D, Zacharin M, Oexle K, Marcelino J, Suwairi W, Heeger S, Sabatakos G, Apte S, Adkins WN, Allgrove J, Arslan-Kirchner M, Batch JA, Beighton P, Black GC, Boles RG, Boon LM, Borrone C, Brunner HG, Carle GF, Dallapiccola B, De Paepe A, Floege B, Halfhide ML, Hall B, Hennekam RC, Hirose T, Jans A, Juppner H, Kim CA, KepplerNoreuil K, Kohlschuetter A, LaCombe D, Lambert M, Lemyre E, Letteboer T, Peltonen L, Ramesar RS, Romanengo M, Somer H, Steichen-Gersdorf E, Steinmann B, Sullivan B, Superti-Furga A, Swoboda W, van den Boogaard MJ, Van Hul W, Vikkula M, Votruba M, Zabel B, Garcia T, Baron R, Olsen BR, Warman ML: LDL receptor-related protein 5 (LRP5) affects bone accrual and eye development. Cell 107:513-523, 2001

70. Van Wesenbeeck L, Cleiren E, Gram J, Beals RK, Benichou O, Scopelliti D, Key L, Renton T, Bartels C, Gong Y, Warman ML, De Vernejoul MC, Bollerslev J, Van Hul W: Six novel missense mutations in the LDL receptor-related protein 5 (LRP5) gene in different conditions with an increased bone density. Am J Hum
Genet 72:763-771, 2003

71. Polakis P: The oncogenic activation of beta-catenin. Curr Opin Genet Dev 9:15-21, 1999

72. Su LK, Vogelstein B, Kinzler KW: Association of the APC tumor suppressor protein with catenins. Science 262:1734-1737, 1993

73. Zeng L, Fagotto F, Zhang T, Hsu W, Vasicek TJ, Perry WL III, Lee JJ, Tilghman SM, Gumbiner BM, Costantini F: The mouse Fused locus encodes Axin, an inhibitor of the Wnt signaling pathway that regulates embryonic axis formation. Cell 90:181-192, 1997

74. Behrens J, Jerchow BA, Wurtele M, Grimm J, Asbrand C, Wirtz R, Kuhl M, Wedlich D, Birchmeier W: Functional interaction of an axin homolog, conductin, with beta-catenin, APC, and GSK3beta. Science 280:596-599, 1998

75. Hart MJ, de Los SR, Albert IN, Rubinfeld B, Polakis P: Downregulation of beta-catenin by human Axin and its association with the APC tumor suppressor, beta-catenin and GSK3 beta. Curr Biol 8:573-581, 1998

76. Ikeda S, Kishida S, Yamamoto H, Murai H, Koyama S, Kikuchi A: Axin, a negative regulator of the Wnt signaling pathway, forms a complex with GSK-3beta and beta-catenin and promotes GSK3beta-dependent phosphorylation of beta-catenin. EMBO Journal 17:1371-1384, 1998

77. Ilyas M, Tomlinson IP, Rowan A, Pignatelli M, Bodmer WF: Betacatenin mutations in cell lines established from human colorectal cancers. Proc Natl Acad Sci USA 94:10330-10334, 1997

78. Sparks AB, Morin PJ, Vogelstein B, Kinzler KW: Mutational analysis of the APC/beta-catenin/Tcf pathway in colorectal cancer. Cancer Res 58:1130-1134, 1998

79. Esteller M, Sparks A, Toyota M, Sanchez-Cespedes M, Capella G, Peinado MA, Gonzalez S, Tarafa G, Sidransky D, Meltzer SJ, Baylin SB, Herman JG: Analysis of adenomatous polyposis coli promoter hypermethylation in human cancer. Cancer Res 60:4366-4371, 2000

80. Mimori-Kiyosue Y, Tsukita S: Where is APC going? J Cell Biol 154:1105-1109, 2001

81. Kaplan KB, Burds AA, Swedlow JR, Bekir SS, Sorger PK, Nathke IS: A role for the Adenomatous Polyposis Coli protein in chromosome segregation. Nat Cell Biol 3:429-432, 2001

82. Fodde R, Kuipers J, Rosenberg C, Smits R, Kielman M, Gaspar C, van Es JH, Breukel C, Wiegant J, Giles RH, Clevers H: Mutations in the APC tumour suppressor gene cause chromosomal instability. Nat Cell Biol 3:433-438, 2001

83. Satoh S, Daigo Y, Furukawa Y, Kato T, Miwa N, Nishiwaki T, Kawasoe T, Ishiguro H, Fujita M, Tokino T, Sasaki Y, Imaoka S, Murata M, Shimano T, Yamaoka Y, Nakamura Y: AXIN1 mutations in hepatocellular carcinomas, and growth suppression in cancer cells by virus-mediated transfer of AXIN1. Nat Genet 24:245-250, 2000

84. He TC, Sparks AB, Rago C, Hermeking H, Zawel L, da Costa LT, Morin PJ, Vogelstein B, Kinzler KW: Identification of c-MYC as a target of the APC pathway. Science 281:1509-1512, 1998

85. Shtutman M, Zhurinsky J, Simcha I, Albanese C, D'Amico M, Pestell R, Ben Ze'ev A: The cyclin D1 gene is a target of the betacatenin/LEF-1 pathway. Proc Natl Acad Sci USA 96:5522-5527, 1999

86. Brown PO, Botstein D: Exploring the new world of the genome with DNA microarrays. Nat Genet 21:33-37, 1999

87. Collins FS, Green ED, Guttmacher AE, Guyer MS: A vision for the future of genomics research. Nature 422:835-847, 2003

88. Luo J, Isaacs WB, Trent JM, Duggan DJ: Looking beyond morphology: cancer gene expression profiling using DNA microarrays. Cancer Invest 21:937-949, 2003

89. Vogelstein B, Kinzler KW: Cancer genes and the pathways they control. Nat Med 10:789-799, 2004 
90. Miklos GL, Maleszka R: Microarray reality checks in the context of a complex disease. Nat Biotechnol 22:615-621, 2004

91. Smalley WE, DuBois RN: Colorectal cancer and nonsteroidal anti-inflammatory drugs. Adv Pharmacol 39:1-20, 1997

92. Thun MJ: Aspirin and gastrointestinal cancer. Adv Exp Med Biol 400A:395-402, 1997

93. Jolly K, Cheng KK, Langman MJ: NSAIDs and gastrointestinal cancer prevention. Drugs 62:945-956, 2002

94. Meyskens FL Jr: Chemoprevention of FAP with sulindac. Curr Oncol Rep 4:463, 2002

95. Mahmoud NN, Boolbol SK, Dannenberg AJ, Mestre JR, Bilinski RT, Martucci C, Newmark HL, Chadburn A, Bertagnolli MM: The sulfide metabolite of sulindac prevents tumors and restores enterocyte apoptosis in a murine model of familial adenomatous polyposis. Carcinogenesis 19:87-91, 1998

96. Dihlmann S, Siermann A, von Knebel DM: The nonsteroidal anti-inflammatory drugs aspirin and indomethacin attenuate betacatenin/TCF-4 signaling. Oncogene 20:645-653, 2001

97. Dihlmann S, Klein S, Doeberitz Mv MK: Reduction of betacatenin/T-cell transcription factor signaling by aspirin and indomethacin is caused by an increased stabilization of phosphorylated beta-catenin. Mol Cancer Ther 2:509-516, 2003

98. Nath N, Kashfi K, Chen J, Rigas B: Nitric oxide-donating aspirin inhibits beta-catenin/T cell factor (TCF) signaling in SW480 colon cancer cells by disrupting the nuclear beta-catenin-TCF association. Proc Natl Acad Sci USA 100:12584-12589, 2003

99. Boon EM, Keller JJ, Wormhoudt TA, Giardiello FM, Offerhaus GJ, van der NR, Pals ST: Sulindac targets nuclear beta-catenin accumulation and Wnt signalling in adenomas of patients with familial adenomatous polyposis and in human colorectal cancer cell lines. Br J Cancer 90:224-229, 2004

100. Naishiro Y, Yamada T, Takaoka AS, Hayashi R, Hasegawa F, Imai K, Hirohashi S: Restoration of epithelial cell polarity in a colorectal cancer cell line by suppression of beta-catenin/T-cell factor 4-mediated gene transactivation. Cancer Res 61:2751-2758, 2001

101. Gardner SH, Hawcroft G, Hull MA: Effect of nonsteroidal antiinflammatory drugs on beta-catenin protein levels and cateninrelated transcription in human colorectal cancer cells. Br J Cancer 91:153-163, 2004

102. He TC, Chan TA, Vogelstein B, Kinzler KW: PPARdelta is an APC-regulated target of nonsteroidal anti-inflammatory drugs. Cell 99:335-345, 1999

103. Davies GL: Cyclooxygenase-2 and chemoprevention of breast cancer. J Steroid Biochem Mol Biol 86:495-499, 2003

104. Goluboff ET: Exisulind, a selective apoptotic antineoplastic drug. Expert Opin Investig Drugs 10:1875-1882, 2001

105. Sharpe C, Lawrence N, Martinez AA: Wnt signalling: a theme with nuclear variations. Bioessays 23:311-318, 2001

106. Klingelhofer J, Troyanovsky RB, Laur OY, Troyanovsky S: Exchange of catenins in cadherin-catenin complex. Oncogene 22:1181-1188, 2003

107. Li H, Pamukcu R, Thompson WJ: beta-Catenin signaling: therapeutic strategies in oncology. Cancer Biol Ther 1:621-625, 2002

108. Shah S, Pishvaian MJ, Easwaran V, Brown PH, Byers SW: The role of cadherin, beta-catenin, and AP-1 in retinoid-regulated carcinoma cell differentiation and proliferation. J Biol Chem 277:25313-25322, 2002

109. Shah S, Hecht A, Pestell R, Byers SW: Trans-repression of betacatenin activity by nuclear receptors. J Biol Chem 278:4813748145,2003

110. Xiao JH, Ghosn C, Hinchman C, Forbes C, Wang J, Snider N, Cordrey A, Zhao Y, Chandraratna RA: Adenomatous polyposis coli (APC)-independent regulation of beta-catenin degradation via a retinoid X receptor-mediated pathway. J Biol Chem 278:2995429962, 2003

111. Mollersen L, Paulsen JE, Olstorn HB, Knutsen HK, Alexander J: Dietary retinoic acid supplementation stimulates intestinal tumour formation and growth in multiple intestinal neoplasia (Min)/+ mice. Carcinogenesis 25:149-153, 2004

112. Wong NA, Pignatelli M: Beta-catenin-a linchpin in colorectal carcinogenesis? Am J Pathol 160:389-401, 2002

113. Hanai J, Gloy J, Karumanchi SA, Kale S, Tang J, Hu G, Chan B, Ramchandran R, Jha V, Sukhatme VP, Sokol S: Endostatin is a potential inhibitor of Wnt signaling. J Cell Biol 158:529-539, 2002

114. Narayan S: Curcumin, a multi-functional chemopreventive agent, blocks growth of colon cancer cells by targeting beta-cateninmediated transactivation and cell-cell adhesion pathways. J Mol Histol 35:301-307, 2004

115. Jaiswal AS, Marlow BP, Gupta N, Narayan S: Beta-cateninmediated transactivation and cell-cell adhesion pathways are important in curcumin (diferuylmethane)-induced growth arrest and apoptosis in colon cancer cells. Oncogene 21:8414-8427, 2002

116. Park CH, Hahm ER, Park S, Kim HK, Yang CH: The inhibitory mechanism of curcumin and its derivative against beta-catenin/Tcf signaling. FEBS Lett 579:2965-2971, 2005

117. Aggarwal BB, Kumar A, Bharti AC: Anticancer potential of curcumin: preclinical and clinical studies. Anticancer Res 23:363398, 2003

118. Chainani-Wu N: Safety and anti-inflammatory activity of curcumin: a component of tumeric (Curcuma longa). J Altern Complement Med 9:161-168, 2003

119. Duvoix A, Blasius R, Delhalle S, Schnekenburger M, Morceau F, Henry E, Dicato M, Diederich M: Chemopreventive and therapeutic effects of curcumin. Cancer Lett 223:181-190, 2005

120. Jaszewski R, Millar B, Hatfield JS, Nogothu K, Finkenauer R, Rishi AK, Naumoff JA, Kucuk O, Axelrod BN, Majumdar AP: Folic acid reduces nuclear translocation of beta-catenin in rectal mucosal crypts of patients with colorectal adenomas. Cancer Lett 206:27-33, 2004

121. Nagothu KK, Rishi AK, Jaszewski R, Kucuk O, Majumdar AP: Folic acid mediated inhibition of serum-induced activation of egfr promoter in colon cancer cells. Am J Physiol Gastrointest Liver Physiol 2004

122. Glass CK, Rosenfeld MG: The coregulator exchange in transcriptional functions of nuclear receptors. Genes Dev 14:121-141, 2000

123. Johnstone RW: Histone-deacetylase inhibitors: novel drugs for the treatment of cancer. Nat Rev Drug Discov 1:287-299, 2002

124. Kramer $\mathrm{OH}$, Gottlicher M, Heinzel $\mathrm{T}$ : Histone deacetylase as a therapeutic target. Trends Endocrinol Metab 12:294-300, 2001

125. Zhu P, Martin E, Mengwasser J, Schlag P, Janssen KP, Gottlicher M: Induction of HDAC2 expression upon loss of APC in colorectal tumorigenesis. Cancer Cell 5:455-463, 2004

126. Bienz M: TCF: transcriptional activator or repressor? Curr Opin Cell Biol 10:366-372, 1998

127. Chen G, Fernandez J, Mische S, Courey AJ: A functional interaction between the histone deacetylase $\mathrm{Rpd} 3$ and the corepressor groucho in Drosophila development. Genes \& Development 13:2218-2230, 1999

128. Nusse R: WNT targets. Repression and activation. Trends Genet $15: 1-3,1999$

129. Bordonaro M, Mariadason JM, Aslam F, Heerdt BG, Augenlicht LH: Butyrate-induced apoptotic cascade in colonic carcinoma cells: modulation of the beta-catenin-Tcf pathway and concordance with effects of sulindac and trichostatin A but not curcumin. 
Cell Growth Differ 10:713-720, 1999

130. Ohira T, Gemmill RM, Ferguson K, Kusy S, Roche J, Brambilla E, Zeng C, Baron A, Bemis L, Erickson P, Wilder E, Rustgi A, Kitajewski J, Gabrielson E, Bremnes R, Franklin W, Drabkin HA: WNT7a induces E-cadherin in lung cancer cells. Proc Natl Acad Sci USA 100:10429-10434, 2003

131. Waltzer L, Bienz M: Drosophila CBP represses the transcription factor TCF to antagonize Wingless signalling. Nature 395:521525,1998

132. Martinez A, Castro A, Dorronsoro I, Alonso M: Glycogen synthase kinase 3 (GSK-3) inhibitors as new promising drugs for diabetes, neurodegeneration, cancer, and inflammation. Med Res Rev 22:373-384, 2002

133. Martinez A, Alonso M, Castro A, Perez C, Moreno FJ: First nonATP competitive glycogen synthase kinase 3 beta (GSK-3beta) inhibitors: thiadiazolidinones (TDZD) as potential drugs for the treatment of Alzheimer's disease. J Med Chem 45:1292-1299, 2002

134. Cohen P, Goedert M: GSK3 inhibitors: development and therapeutic potential. Nat Rev Drug Discov 3:479-487, 2004

135. Meijer L, Flajolet M, Greengard P: Pharmacological inhibitors of glycogen synthase kinase 3. Trends Pharmacol Sci 25:471-480, 2004

136. Alonso M, Martinez A: GSK-3 inhibitors: discoveries and developments. Curr Med Chem 11:755-763, 2004

137. Klein PS, Melton DA: A molecular mechanism for the effect of lithium on development. Proc Natl Acad Sci USA 93:8455-8459, 1996

138. Zhang F, Phiel CJ, Spece L, Gurvich N, Klein PS: Inhibitory phosphorylation of glycogen synthase kinase-3 (GSK-3) in response to lithium. Evidence for autoregulation of GSK-3. J Biol Chem 278:33067-33077, 2003

139. Jope RS: Lithium and GSK-3: one inhibitor, two inhibitory actions, multiple outcomes. Trends Pharmacol Sci 24:441-443, 2003

140. Blaheta RA, Cinatl J Jr: Anti-tumor mechanisms of valproate: a novel role for an old drug. Med Res Rev 22:492-511, 2002

141. Tariot PN, Loy R, Ryan JM, Porsteinsson A, Ismail S: Mood stabilizers in Alzheimer's disease: symptomatic and neuroprotective rationales. Adv Drug Deliv Rev 54:1567-1577, 2002

142. Gould TD, Manji HK: The Wnt signaling pathway in bipolar disorder. Neuroscientist 8:497-511, 2002

143. Zhou L, An N, Haydon RC, Zhou Q, Cheng H, Peng Y, Jiang W, Luu HH, Vanichakarn P, Szatkowski JP, Park JY, Breyer B, He TC: Tyrosine kinase inhibitor STI-571/Gleevec down-regulates the beta-catenin signaling activity. Cancer Lett 193:161-170, 2003

144. Ross JA, Kasum CM: Dietary flavonoids: bioavailability, metabolic effects, and safety. Annu Rev Nutr 22:19-34, 2002

145. Lee JH, Park CH, Jung KC, Rhee HS, Yang CH: Negative regulation of beta-catenin/Tcf signaling by naringenin in AGS gastric cancer cell. Biochem Biophys Res Commun 335:771-776, 2005

146. Park CH, Hahm ER, Lee JH, Jung KC, Yang CH: Inhibition of beta-catenin-mediated transactivation by flavanone in AGS gastric cancer cells. Biochem Biophys Res Commun 331:1222-1228, 2005

147. Park CH, Chang JY, Hahm ER, Park S, Kim HK, Yang CH: Quercetin, a potent inhibitor against beta-catenin/Tcf signaling in SW480 colon cancer cells. Biochem Biophys Res Commun 328:227-234, 2005

148. Park CH, Hahm ER, Lee JH, Jung KC, Lee HS, Yang CH: Ionomycin downregulates $\{$ beta $\}$-catenin/Tcf signaling in colon cancer cell line. Carcinogenesis 2005

149. Willert K, Brown JD, Danenberg E, Duncan AW, Weissman IL, Reya T, Yates JR III, Nusse R: Wnt proteins are lipid-modified and can act as stem cell growth factors. Nature 423:448-452, 2003

150. Nusse R, Varmus HE: Wnt genes. Cell 69:1073-1087, 1992

151. Bhanot P, Brink M, Samos CH, Hsieh JC, Wang Y, Macke JP, Andrew D, Nathans J, Nusse R: A new member of the frizzled family from Drosophila functions as a Wingless receptor. Nature 382:225-230, 1996

152. Hsieh JC, Rattner A, Smallwood PM, Nathans J: Biochemical characterization of Wnt-frizzled interactions using a soluble, biologically active vertebrate Wnt protein. Proceedings of the National Academy of Sciences of the United States of America 96:3546-3551, 1999

153. Hsieh JC: Specificity of WNT-receptor interactions. Front Biosci 9:1333-1338, 2004

154. George SR, O’Dowd BF, Lee SP: G-protein-coupled receptor oligomerization and its potential for drug discovery. Nat Rev Drug Discov 1:808-820, 2002

155. Pandur P, Kuhl M: An arrow for wingless to take-off. Bioessays 23:207-210, 2001

156. Wharton KA Jr: Runnin' with the Dvl: proteins that associate with Dsh/Dvl and their significance to Wnt signal transduction. Dev Biol 253:1-17, 2003

157. Bhat RV, Budd Haeberlein SL, Avila J: Glycogen synthase kinase 3: a drug target for CNS therapies. J Neurochem 89:1313-1317, 2004

158. Cohen P, Goedert M: GSK3 inhibitors: development and therapeutic potential. Nat Rev Drug Discov 3:479-487, 2004

159. Gould TD, Gray NA, Manji HK: Effects of a glycogen synthase kinase-3 inhibitor, lithium, in adenomatous polyposis coli mutant mice. Pharmacol Res 48:49-53, 2003

160. Wagman AS, Johnson KW, Bussiere DE: Discovery and development of GSK 3 inhibitors for the treatment of type 2 diabetes. Curr Pharm Des 10:1105-1137, 2004

161. Kim JS, Crooks H, Foxworth A, Waldman T: Proof-of-principle: oncogenic beta-catenin is a valid molecular target for the development of pharmacological inhibitors. Mol Cancer Ther 1:13551359,2002

162. Verma UN, Surabhi RM, Schmaltieg A, Becerra C, Gaynor RB: Small Interfering RNAs Directed against beta-Catenin Inhibit the in Vitro and in Vivo Growth of Colon Cancer Cells. Clin Cancer Res 9:1291-1300, 2003

163. Bennett CF, Cowsert LM: Antisense modulation of beta-catenin expression. US Patent No. 6,066,500. 2000

164. Tetsu O, McCormick F: Beta-catenin regulates expression of cyclin D1 in colon carcinoma cells. Nature 398:422-426, 1999

165. van de Wetering M., Sancho E, Verweij C, de Lau W, Oving I, Hurlstone A, van der HK, Batlle E, Coudreuse D, Haramis AP, Tjon-Pon-Fong M, Moerer P, van den BM, Soete G, Pals S, Eilers M, Medema R, Clevers H: The beta-catenin/TCF-4 complex imposes a crypt progenitor phenotype on colorectal cancer cells. Cell 111:241-250, 2002

166. Rother K, Johne C, Spiesbach K, Haugwitz U, Tschop K, Wasner M, Klein-Hitpass L, Moroy T, Mossner J, Engeland K: Identification of Tcf- 4 as a transcriptional target of p53 signalling. Oncogene 23:3376-3384, 2004

167. Lepourcelet M, Chen YN, France DS, Wang H, Crews P, Petersen F, Bruseo C, Wood AW, Shivdasani RA: Small-molecule antagonists of the oncogenic Tcf/beta-catenin protein complex. Cancer Cell 5:91-102, 2004

168. Blaschuk OW, Byers S, Gour BJ: Compounds and methods for modulating beta-catenin mediated gene expression. US Patent No. 6,303,576. 2001

169. Moll J, Knapp S, Dalvit C, Trosset JY, Sundstrom M, Mantegani $\mathrm{S}$ : Interaction inhibitors of TCF-4 with beta-catenin. Pharmacia Italia SPA. US Patent No. EP1406889, 14 April 2004 
170. Emami KH, Nguyen C, Ma H, Kim DH, Jeong KW, Eguchi M, Moon RT, Teo JL, Oh SW, Kim HY, Moon SH, Ha JR, Kahn M: A small molecule inhibitor of beta-catenin/cyclic AMP response element-binding protein transcription. Proc Natl Acad Sci USA 101:12682-12687, 2004

171. Kahn M, Eguch M, Moon SH, Chung JU, Jeong KW: Compounds useful for treatment of cancer, compositions containing the same, and methods of their use. Choongwae Pharma Corporation. US Patent No. 6,762,185. 2004

172. Chrivia JC, Kwok RP, Lamb N, Hagiwara M, Montminy MR, Goodman RH: Phosphorylated CREB binds specifically to the nuclear protein CBP. Nature 365:855-859, 1993

173. Eckner R, Ewen ME, Newsome D, Gerdes M, DeCaprio JA, Lawrence JB, Livingston DM: Molecular cloning and functional analysis of the adenovirus E1A-associated $300-\mathrm{kD}$ protein (p300) reveals a protein with properties of a transcriptional adaptor. Genes Dev 8:869-884, 1994

174. Janknecht R, Hunter T: Versatile molecular glue. Transcriptional control. Curr Biol 6:951-954, 1996

175. Takemaru KI, Moon RT: The transcriptional coactivator CBP interacts with beta-catenin to activate gene expression. J Cell Biol 149:249-254, 2000

176. Easwaran V, Pishvaian M, Salimuddin, Byers S: Cross-regulation of beta-catenin-LEF/TCF and retinoid signaling pathways. Current Biology 9:1415-1418, 1999

177. Minucci S, Pelicci PG: Retinoid receptors in health and disease: co-regulators and the chromatin connection. Semin Cell Dev Biol 10:215-225, 1999

178. Daniels DL, Eklof SK, Weis WI: beta-catenin: molecular plasticity and drug design. Trends Biochem Sci 26:672-678, 2001

179. Omer CA, Miller PJ, Diehl RE, Kral AM: Identification of Tcf4 residues involved in high-affinity beta-catenin binding. Biochem Biophys Res Commun 256:584-590, 1999

180. Graham TA, Weaver C, Mao F, Kimelman D, Xu W: Crystal Structure of a beta-Catenin/Tcf Complex. Cell 103:885-896, 2000

181. Spink KE, Polakis P, Weis WI: Structural basis of the Axinadenomatous polyposis coli interaction. EMBO J 19:2270-2279, 2000

182. Spink KE, Fridman SG, Weis WI: Molecular mechanisms of betacatenin recognition by adenomatous polyposis coli revealed by the structure of an APC-beta-catenin complex. EMBO J 20:62036212,2001

183. Graham TA, Ferkey DM, Mao F, Kimelman D, Xu W: Tcf4 can specifically recognize beta-catenin using alternative conformations. Nat Struct Biol 8:1048-1052, 2001

184. Poy F, Lepourcelet M, Shivdasani RA, Eck MJ: Structure of a human Tcf4-beta-catenin complex. Nat Struct Biol 8:1053-1057, 2001

185. Moon RT, Kohn AD, De Ferrari GV, Kaykas A: WNT and betacatenin signalling: diseases and therapies. Nat Rev Genet 5:691701, 2004

186. Smalley MJ, Dale TC: Wnt signalling in mammalian development and cancer. Cancer \& Metastasis Reviews 18:215-230, 1999

187. Janssens N, Andries L, Janicot M, Perera T, Bakker A: Alteration of frizzled expression in renal cell carcinoma. Tumour Biol 25:161-171, 2004

188. Shakoori A, Ougolkov A, Yu ZW, Zhang B, Modarressi MH, Billadeau DD, Mai M, Takahashi Y, Minamoto T: Deregulated GSK3beta activity in colorectal cancer: Its association with tumor cell survival and proliferation. Biochem Biophys Res Commun 334:1365-1373, 2005
189. Manoukian AS, Woodgett JR: Role of glycogen synthase kinase-3 in cancer: regulation by Wnts and other signaling pathways. Adv Cancer Res 84:203-229, 2002

190. Miyaoka T, Seno H, Ishino H: Increased expression of Wnt-1 in schizophrenic brains. Schizophrenia Research 38:1-6, 1999

191. Kozlovsky N, Regenold WT, Levine J, Rapoport A, Belmaker RH, Agam G: GSK-3beta in cerebrospinal fluid of schizophrenia patients. J Neural Transm 111:1093-1098, 2004

192. Yang J, Si T, Ling Y, Ruan Y, Han Y, Wang X, Zhang H, Kong Q, Li X, Liu C, Zhang D, Zhou M, Yu Y, Liu S, Shu L, Ma D, Wei J, Zhang D: Association study of the human FZD3 locus with schizophrenia. Biol Psychiatry 54:1298-1301, 2003

193. Sen M, Lauterbach K, El Gabalawy H, Firestein GS, Corr M, Carson DA: Expression and function of wingless and frizzled homologs in rheumatoid arthritis. Proceedings of the National Academy of Sciences of the United States of America 97:27912796,2000

194. Sen M, Chamorro M, Reifert J, Corr M, Carson DA: Blockade of Wnt-5A/frizzled 5 signaling inhibits rheumatoid synoviocyte activation. Arthritis Rheum 44:772-781, 2001

195. Loughlin J, Dowling B, Chapman K, Marcelline L, Mustafa Z, Southam L, Ferreira A, Ciesielski C, Carson DA, Corr M: Functional variants within the secreted frizzled-related protein 3 gene are associated with hip osteoarthritis in females. Proc Natl Acad Sci USA 101:9757-9762, 2004

196. Boyden LM, Mao J, Belsky J, Mitzner L, Farhi A, Mitnick MA, Wu D, Insogna K, Lifton RP: High bone density due to a mutation in LDL-receptor-related protein 5. N Engl J Med 346:1513-1521, 2002

197. Niemann S, Zhao C, Pascu F, Stahl U, Aulepp U, Niswander L, Weber JL, Muller U: Homozygous WNT3 mutation causes tetra-amelia in a large consanguineous family. Am J Hum Genet 74:558-563, 2004

198. Robitaille J, MacDonald ML, Kaykas A, Sheldahl LC, Zeisler J, Dube MP, Zhang LH, Singaraja RR, Guernsey DL, Zheng B, Siebert LF, Hoskin-Mott A, Trese MT, Pimstone SN, Shastry BS, Moon RT, Hayden MR, Goldberg YP, Samuels ME: Mutant frizzled-4 disrupts retinal angiogenesis in familial exudative vitreoretinopathy. Nat Genet Frizzled 2002

199. Toomes C, Bottomley HM, Jackson RM, Towns KV, Scott S, Mackey DA, Craig JE, Jiang L, Yang Z, Trembath R, Woodruff G, Gregory-Evans CY, Gregory-Evans K, Parker MJ, Black GC, Downey LM, Zhang K, Inglehearn CF: Mutations in LRP5 or FZD4 underlie the common familial exudative vitreoretinopathy locus on chromosome 11q. Am J Hum Genet 74:721-730, 2004

200. Jordan BK, Shen JH, Olaso R, Ingraham HA, Vilain E: Wnt4 overexpression disrupts normal testicular vasculature and inhibits testosterone synthesis by repressing steroidogenic factor $1 /$ betacatenin synergy. Proc Natl Acad Sci USA 100:10866-10871, 2003

201. Biason-Lauber A, Konrad D, Navratil F, Schoenle EJ: A WNT4 mutation associated with Mullerian-duct regression and virilization in a 46,XX woman. N Engl J Med 351:792-798, 2004

Address for offprints: Tim Perera, Johnson \& Johnson Pharmaceutical R \& D, Oncology Discovery Research \& Early Development, Turnhoutseweg 30 B-2340, Beerse, Belgium. Tel.: +32 146058 95, Fax: +32 146054 03; E-mail: tperera@prdbe.jnj.com 